\title{
15-Lipoxygenase and its metabolites in the pathogenesis of breast cancer: A double- edged sword
}

\author{
Mohammad Amin Vaezi ', Banafsheh Safizadeh', Amir Reza Eghtedari', Seyedeh Sara Ghorbanhosseini², \\ Mostafa Rastegar ${ }^{3}$, Vahid Salimi ${ }^{4}$ and Masoumeh Tavakoli-Yaraki ${ }^{1 *}$ (i)
}

\begin{abstract}
15-lipoxygenase is one of the key enzymes for the metabolism of unsaturated fatty acids that its manipulation has been proposed recently as a new molecular target for regulating cancer cell growth. Aberrant expression of 15lipoxygenase enzyme seems to play an indicative role in the pathology of different cancer types, tumor progression, metastasis, or apoptosis. Based on the fact that breast cancer is one of the most common cancers that imposes a burden of mortality in women also, on the other hand, evidence in experimental models and human studies indicate the emerging role of the 15-lipoxygenase pathway in breast cancer pathogenesis, we present a review of recent findings related to the role of 15- lipoxygenase enzyme and metabolites in breast cancer growth, apoptosis, metastasis, and invasion as well as their local and circulating expression pattern in patients with breast cancer. Our review supports the emerging role of 15- lipoxygenase in molecular and cellular processes regulating breast tumor cell fate with both positive and negative effects.
\end{abstract}

Keywords: 15-lipoxygenase-1, 15-lipoxygenase-2, Breast cancer, Cell growth, Apoptosis, Metastasis

\section{Metabolism of arachidonic acid, as a long-chain polyunsaturated fatty acid}

Omega- 3 and omega- 6 fatty acids are a family of polyunsaturated fatty acids (PUFA) that play a vital role in the body's physiological activities due to their presence in cell membranes [1]. Dietary PUFAs include alphalinolenic acid (ALA), as a short-chain omega-3 fatty acid, and linoleic acid (LA) as a short-chain omega-6 fatty acid, also, eicosapentaenoic acid (EPA), docosahexaenoic acid (DHA), and arachidonic acid (AA) as longer chain omega-3 PUFAs [2]. AA can be produced from the essential fatty acids LA or ALA, direct intake from diet, or release from phospholipid pool by the action of phospholipase A2. The biosynthesis pathway of

\footnotetext{
* Correspondence: tavakoli.m@iums.ac.ir; masoumeh.tavakoli@gmail.com 'Department of Biochemistry, School of Medicine, Iran University of Medical Sciences, P.O. Box: 1449614535, Tehran, Iran

Full list of author information is available at the end of the article
}

eicosanoids (bioactive 20-carbon lipid mediators) starts with the conversion of LA to ALA due to the catalytic activity of desaturase. Then, under the influence of the enzyme elongase, this compound is converted to AA, which is a fatty acid with 20 carbon atoms and 4 double bonds [3]. AA can produce eicosanoids through three enzymatic pathways including several oxygenases that generate a spectrum of oxygenated products. One metabolizing way is the cyclooxygenase (COX) pathway, which produces different prostaglandin (PG), such as prostaglandin E (PGE) and PGD, and thromboxane (TX), such as thromboxane A2 (TXA2) and TXA3, and prostacyclins such as prostacyclin I2 and I3 [4]. Two distinct isoforms of the COX enzyme exist, namely COX-1 and COX-2 that are constitutively expressed in most types of cells, although COX-2 is the most regulated type of the COX enzyme that its expression is induced in inflammation and proliferative diseases. Therefore, 
COX inhibitors appeared to be effective in the treatment of pain, inflammation, stroke, and cancer [2]. The cytochrome $\mathrm{P} 450$ (CYP) is the second metabolizing pathway of AA that mainly produces hydroxyeicosatetraenoic acids (HETEs) due to its $\omega$-hydroxylase activity. However, CYP epoxygenase activity resulted in producing epoxyeicosatrienoic acids (EETs) that can further have metabolized by epoxide hydrolase and generate the corresponding diols [5]. Pieces of evidence revealed the vasodilatation effect of EETs as well as their regulatory role on the tumorigenesis process [6]. The last metabolizing way is the lipoxygenase (LOX) pathway that mainly generates leukotrienes (LT), such as LTA4, LTB4, LTC4, LTD4, and LTE4, as well as lipoxins A4, B4, C4, D4, and E4 [7]. LOX pathway is becoming dominant recently as a therapeutic target in many diseases due to its pivotal role in cellular signaling and novel mediators related to this pathway that has been discovered, therefore, the metabolic pathway of LOX is examined in more detail in the next section.

\section{The role of the 15-LOX metabolizing pathway in the metabolism of polyunsaturated fatty acids}

LOX enzymes are a family of iron (non-heme) dioxygenases that can transport oxygen molecules into the free or esterified unsaturated fatty acids. These enzymes are divided into four categories based on the position that the oxygen group enters: lipoxygenase types 5,8 , 12 , and 15 [8]. The LOX enzyme uses two major substrates in cells, including AA, a polyunsaturated omega6 fatty acid $(20: 4(5,8,11,14))$, and LA, a polyunsaturated omega- 6 fatty acid $(8,2$ cis-9,12). The primary product of the enzymatic function of lipoxygenase is hydro peroxy n-6 fatty acids, which are rapidly converted to hydroxy derivatives. Membrane phospholipids are converted to arachidonic acid by phospholipase A4 and phospholipase $\mathrm{C}$, and then AA can be metabolized by lipoxygenase enzymes. The lipoxygenase metabolizes AA and converts it to cyclic hydroperoxides such as hydroperoxy eicosatetraenoicacid (HpETE), Hydroxyeicosatetraenoic acid (HETE), and LTA4. The active metabolites of HpETE are then reduced and converted to HETE. The next substrate for LOX is LA, which is converted to 13Hydroxyoctadecadienoic acid (13-HODE) [9, 10]. Among all types of lipoxygenases, 15-lipoxygenase (15LOX), is the target of this study due to its extensive and regulatory roles in cancer pathogenesis. 15-LOX, formerly known as arachidonate lipoxygenase, is made up of two types of isoenzymes: 15-lipoxygenase type 1 (15-LOX-1), and 15- lipoxygenase type 2 (15-LOX-2, 8]. 15 -LOX is mainly expressed in reticulocytes, eosinophils and epithelial cells, including respiratory epithelium and macrophages [10]. Intracellular 15-LOX activity is highly regulated and the regulation of this enzyme occurs at the levels of transcription, translation, and posttranslation in different cellular systems. The results of previous studies showed that 15 -LOX at the transcriptional level can be induced by interleukins [11]. In human monocytes, adenocarcinoma human alveolar basal epithelial cells (A549 cell line), and human colorectal adenocarcinoma cells (Caco2 cell line), 15-LOX expression level was induced following treatment with interleukin 4 (IL4). It was shown that activation of IL4 cell surface receptor, resulted in the activation of signal transducer and activator of transcription 6 (STAT6), and transport of its phosphorylated homodimer to the nucleus to bind to STAT6-responsible agents including IL4-related genes such as 15-LOX [12]. Notably, 15LOX-1 transcription can be activated both in a STAT6dependent and independent manner via histone modification of the 15-LOX promotor [13]. Also, it was shown that Interleukin-13 (IL-13) induces the 15-LOX-1 expression and activity that resulted in the elevation of 15LOX-1 metabolites, activation of peroxisome proliferator-activated receptor-gamma (PPAR- $\gamma$ ), initiation of apoptosis in glioblastoma cells [14]. On the other hand, the transcriptional activity of PPAR $\gamma$ can be facilitated by STAT6 indicating the crucial role of the IL13-15-LOX-PPAR $\gamma$ axis in regulating cell growth and invasion [15]. Besides, it was postulated that 15-LOX expression can be regulated by acetylation of histones in the nucleus [16]. Moreover, Nitric oxide (NO) is assumed to be another regulatory factor for 15-LOX activity, as it was revealed that incubation of 15-LOX for a short time with NO increases the length of the catalytic period of the enzyme, which can cause reversible inhibition of the enzyme [17]. Another important regulatory factor at the post-translational level is the membrane binding ability of 15-LOX in a calcium-dependent manner. When the 15-LOX enzyme was incubated with biological membranes in the presence of calcium ions, the enzyme's ability to bind to the membrane enhanced that was associated with a 10-fold increase in the enzyme's catalytic ability to oxidize fatty acids [18]. The 15-LOX the enzyme is involved in various cellular processes, including cell differentiation, development, mitochondrial degradation, and reticulocyte maturation [19-21]. Levels of 15-LOX products $(15(S)$ - hydroperoxy eicosatetraenoic acid (15-S-HETE), 3(S)-hydroxy-9Z,11E-octadecadienoic acid (13(S)-HODE)) in tissues usually increase during inflammation [22]. However, the role of lipoxygenase enzymes in the development and spread of cancer is very complex and controversial. Evaluating the expression and activity level of lipoxygenases in epithelial cancerous and normal tissues in humans and mice shows that 15-LOX- type 1 and 2 are preferably expressed more in normal /benign tissues than cancerous tissues of the bladder [23], breast [24], colon [25], 
lung [26] and prostate [19]. However, conflicting evidence exists regarding the 15-LOX expression pattern in the aforementioned tissues. Based on shreds of evidence, LOX isoforms revealed both anti-tumorigenic and protumorigenic effects in different tumor tissues [16, 27]. In breast cancer, both isoforms of 15- LOX are downregulated in the cancerous epithelium than in the normal tissue, while a high level of the enzymes 12 and 5LOX are expressed in the breast cancer sample and tissue [28]. The results of other studies show that increasing the expression level of 12-LOX and decreasing the level of 15-LOX in breast cancer patients play a prognostic role [29]. Similarly, in non-Small Cell Lung Cancer (NSCLC), the expression of 15-LOX-2 increased in well-differentiated tumors [26]. It can be concluded that the role of LOX expression in cancer growth depends on the type of tissue and the type of isoform that is expressed. To find the role of each isoform in cancer progression, it is necessary to examine the role of LOX metabolism in various aspects of cancer development, including cell growth, cell invasion, angiogenesis, and metastasis. In this review, we present recent evidence and findings indicating the role of the 15-LOX pathway in breast cancer and we also discuss the significance and importance of 15-LOX enzyme isoforms and main products on breast cancer cell growth, death, metastasis, and invasion. Identifying the role of the 15-LOX pathway, as a critical pathway in the process of lipid metabolism, in breast cancer pathogenesis may enhance our understanding of the putative mechanisms underlying breast tumor onset and progression and also may open up promising solutions for more effective treatments of this cancer.

\section{How 15-LOX works in a breast normal and tumor cell and what is the 15-LOX putative mechanism of action?}

Given the breadth of 15-LOX-mediated cell death in breast tumors, the expression level of 15-LOX and its products have been surveyed in several studies that are summarized in Table 1. Evaluating the transcript level of 15-LOX in tumor tissues of patients with breast cancer showed a significant reduction of 15-LOX expression level compared to the normal breast tissues in nodepositive patients [24]. The attenuated level of 15-LOX was associated with tumor stage and grade since the lowest level of 15-LOX was detected in TNM4 breast tumors. Also, the lower level of 15-LOX was detected in Lobular carcinomas compared to the ductal breast tumors [24]. Alongside with 15-LOX reduced level, overexpression of 12-LOX and cyclooxygenase-2 (COX-2) was observed in breast tumor tissues while 5-LOX level remained un-changed in breast tumor and normal tissues [28]. In accordance, it was shown that both 15-
LOX isoforms (15-LOX-1 and 15-LOX-2) were expressed in breast normal epithelial cells and vascular endothelial cells while breast tumor cells showed lower protein levels of both 15-LOX isoforms compared to the normal breast cells. Also, in node-positive tumors, the 15-LOX-1 transcript was lower compared to the nodenegative tumors. In addition, the lower level of 15-LOX2: Cytokeratin 19 (CK19) ratio was detected in TNM3 tumors compared to TNM1 tumors indicating the trend of high grades tumors to down-regulate 15 -LOX isoforms. Interestingly, in estrogen receptor (ER)-positive breast tumors, the expression level of 15-LOX-2 was reduced in the corresponding cells while the 15-LOX-1 expression level remained unchanged compared to the ERnegative tumors. The association of metastasis occurrence and development, tumor recurrence, and patient survival with a lower level of 15-LOX-2 and 15-LOX-1 was detected in patients with breast cancer. Based on the findings, the 15LOX1:15LOX2 ratio has prognostic value in predicting the clinical outcome of patients with breast cancer [24]. A high level of the 15-LOX-2 transcript was detected in normal prostate, breast, bladder, and skin tissues, while the expression level of 15-LOX-2 reduced remarkably in tumors of the mentioned tissues $[30,35,36]$. It might be explained by the hypothesis that 15-LOX-2 is localized in Golgi-like structures inside the normal epithelial cells, however, the mentioned structures are not found in the transformed cells. It was revealed that the 15-LOX-2 product (15-S-HETE) level was elevated in normal cells while reduced in the correspondence tumor cells. The regulatory role of PPAR- $\gamma$ was demonstrated in the study of Subbarayan et al.; that based on their report, stimulation of PPAR- $\gamma$ expression caused down-regulation of 15-LOX-2 in breast and lung normal epithelial cells. Accordingly, over-expression of 15-LOX-2 or 15-S-HETE in tumor cells was accompanied by reduced PPAR- $\gamma$ protein level [30]. In another survey, the preoperative serum level of prostaglandin E2

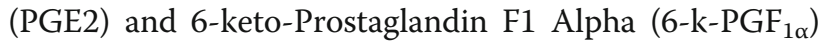
in patients with malignant breast tumors was significantly higher compared to the postoperative levels of PGE2 and 6-k-PGF $1 \alpha$ [31]. The eicosanoid profile of breast tumor tissues indicated that the eicosanoid metabolites except for prostaglandin $\mathrm{F} 2 \alpha\left(\mathrm{PGF}_{2 \alpha}\right)$, heptadecatrienoic acid (HHT), and 15-Hydroxyeicosatetraenoic acid (15-HETE) were higher compared to the benign breast tumor or mammary reduction. A correlation was observed between tumor value of LOX products such as (15-HETE) and 13,14-dihydro-15-keto-prostaglandin (DHKPG) with tumor diameter and fibrosis score. As a result, the eicosanoid synthesis profile showed a different pattern in mammary tumors and normal tissues [31]. In an in-vitro study, it was observed that 13(S)-HODE suppressed the growth of MCF-7 and MDA-MB-231 breast 
Table 1 The expression pattern of 15-LOX and its metabolites in breast cancer

\begin{tabular}{|c|c|c|c|c|}
\hline $\begin{array}{l}\text { Type of } 15 \text {-LOX en- } \\
\text { zyme/ metabolites/ } \\
\text { other mediators }\end{array}$ & $\begin{array}{l}\text { Transcript/ } \\
\text { protein } \\
\text { level }\end{array}$ & $\begin{array}{l}\text { Cell line/Human tissue type/ } \\
\text { serum }\end{array}$ & Observations & Ref \\
\hline 15-LOX & mRNA & Tumor breast tissue & $\begin{array}{l}\text { - Reduction of 15-LOX level in tumor tissue } \\
\text { - Association of lower expression level with tumor stage } \\
\text { - Lower level of 15-LOX in Lobular carcinomas }\end{array}$ & [28] \\
\hline $\begin{array}{l}15-\mathrm{LOX}-1 \\
15-\mathrm{LOX}-2\end{array}$ & $\begin{array}{l}\text { mRNA } \\
\text { Protein }\end{array}$ & $\begin{array}{l}\text { breast normal epithelial cells/ } \\
\text { breast tumor tissues/ vascular } \\
\text { endothelial cells }\end{array}$ & $\begin{array}{l}\text { - Tumor tissues showed lower protein level of both } 15-\mathrm{LOX} \text { iso- } \\
\text { forms compared to breast normal/ vascular endothelial cells } \\
\text { - Association of 15-LOX isoforms down regulation with tumor se- } \\
\text { verity, recurrence, metastasis and patient's survival } \\
\text { - Reduction of 15-LOX-2 and no change in 15-LOX-1 in ER-positive } \\
\text { breast tumors }\end{array}$ & [24] \\
\hline $\begin{array}{l}\text { 15-LOX-2 } \\
15-\mathrm{S}-\mathrm{HETE}\end{array}$ & mRNA & Tumor/normal breast tissue & $\begin{array}{l}\text { - High level of } 15-\text { LOX-2 transcript in normal vs tumor breast } \\
\text { tissue } \\
\text { - High level of 15-S-HETE in normal cells vs tumor cells } \\
\text { - PPAR-y mediates down-regulation of } 15-\text { LOX-2 }\end{array}$ & [30] \\
\hline $\begin{array}{l}\text { Eicosanoid metabolites } \\
15 \text {-S-HETE }\end{array}$ & $\begin{array}{l}\text { Final } \\
\text { product }\end{array}$ & Breast tumor tissues & $\begin{array}{l}\text { - } \text { PGF }_{2 a}, \mathrm{HHT} \text { and } 15 \mathrm{HETE} \text { were lower in tumors vs compared to } \\
\text { the benign breast tumor or mammary reduction } \\
\text { - Correlation between tumor value of } 15 \text {-HETE with tumor diam- } \\
\text { eter and fibrosis score }\end{array}$ & [31] \\
\hline 15-LOX-2 PPAR- $\gamma$ & $\begin{array}{l}\text { mRNA } \\
\text { Protein }\end{array}$ & $\begin{array}{l}\text { Normal epithelial cells/ malignant } \\
\text { breast tumor tissue }\end{array}$ & $\begin{array}{l}\text { - Normal epithelial cells expressed high level of 15-LOX-2 gene } \\
\text { and protein while low level of PPAR- }- \\
\text { - Malignant breast tumors/ breast (MDA453) cells low level of 15- } \\
\text { LOX-2 and high level of PPAR- } \gamma \\
\text { - breast (MCF-7 and SK-BR-3) expressed low level of 15-LOX-2 } \\
\text { gene and protein while the level of PPAR- } \gamma \text { was not as high as } \\
\text { the other malignant epithelial cells }\end{array}$ & {$[30]$} \\
\hline 15-LOX & mRNA & $\begin{array}{l}\text { MB231, H2380, SKBR3, T47D, } \\
\text { ZR75, MCF-WT MCF7-adr }\end{array}$ & $\begin{array}{l}\text { - SKBR3 cells was not able to express } 15-\text { LOX, while the rest of } \\
\text { breast cancer cells expressed 15-LOX. } \\
\text { - Dual inhibition of LOX/COX enzymes and general inhibition of } \\
\text { LOX enzymes caused growth inhibition in SKBR3, ZR75,T47D } \\
\text { cells. }\end{array}$ & [32] \\
\hline $\begin{array}{l}\text { 13-HODE, } \\
\text { 9-HODE } \\
\text { 13-HOTrE } \\
\text { 9-HOTrE } \\
\text { 12-HHTrE }\end{array}$ & $\begin{array}{l}\text { Final } \\
\text { product }\end{array}$ & $\begin{array}{l}\text { Plasma of patients with breast } \\
\text { cancer }\end{array}$ & $\begin{array}{l}\text { - 13-HODE, 9-HODE, 13-HOTrE, 9-HOTrE, and 12-HHTrE were ele- } \\
\text { vated in the plasma of the breast cancer patients }\end{array}$ & [33] \\
\hline $\begin{array}{l}\text { 13-HODE } \\
\text { 15-HETE, 12-HETE } \\
\text { 5-HETE } \\
\text { 5-OXO-ETE PGD2 } \\
\text { PGE2 }\end{array}$ & $\begin{array}{l}\text { Final } \\
\text { product }\end{array}$ & $\begin{array}{l}\text { Breast tumor tissues/ breast } \\
\text { normal tissues/ MDA-MB-231/ } \\
\text { MCF-7 }\end{array}$ & $\begin{array}{l}\text { - 13-HODE, 15-HETE, 12-HETE, 5-HETE, 5-OXo-ETE, PGD2, and PGE2 } \\
\text { metabolites were expressed in malignant and most of normal } \\
\text { breast tissues. } \\
\text { - } 13 \text {-HODE expression was correlated with aggressive grade and } \\
\text { lymph node metastasis. } \\
\cdot 13-\mathrm{HODE} \text { and } 15-\mathrm{HETE} \text { induced proliferation of MDA-MB-231 and } \\
\text { MCF-7. }\end{array}$ & [34] \\
\hline
\end{tabular}

cancer cell lines in a dose/time-dependent manner. Moreover, the increasing concentration of 13(S)-HODE was accompanied by the accumulation of cells in the Sub-G1 phase of the cell cycle and the induction of early apoptosis. It was shown that the expression level of PPAR $-\gamma$ was attenuated following treatment of breast cancer cells with 13(S)-HODE [37]. To clarify the expression status of 15 -LOX-2 and its relationship with PPAR- $\gamma$, various normal and tumor tissues from epithelial and non-epithelial sources were enrolled in the survey. The normal epithelial cells derived from prostate, breast, lung, bladder, and skin tissues, expressed a high level of 15-LOX-2 gene and protein while low level of PPAR- $\gamma$. In contrast, the malignant tumors and the transformed epithelial cells of the prostate (PC-3 and
DU145), breast (MDA453), lung (Calu I), bladder (U-9 and $\mathrm{U}-14)$, skin $(\mathrm{HaCaT})$, and pancreas (Mia PaCa-2 and ASPC-1) exhibited a low level of 15-LOX-2 and high level of PPAR- $\gamma$. However, other epithelial cells of the same tissues including prostate (LNCaP), lung (MSK-3), breast (MCF-7 and SK-BR-3), and skin (SCC-M7 and SCC-P9), expressed a low level of 15-LOX-2 gene and protein while the level of PPAR- $\gamma$ was not as high as the other malignant epithelial cells [30]. Treatment of MCF7 cells with arachidonic acid and 15-L-(S)- hydroperoxy eicosatetraenoic acid (15-L-(S)-HPETE) induced cell toxicity in a time and dose-dependent manner and the cytotoxic effect of $15-\mathrm{L}-(\mathrm{s})$-HPETE, as a $15-\mathrm{LOX}$ product was more remarkable [38]. It was found that 15-LOX-1 suppressed tumor growth and metastasis development in 
transgenic mice with mammary gland carcinoma and/ also mice with Lewis lung carcinoma [39]. In addition to studies that reported the decreased expression of the 15LOX and its products, significant studies have shown that the LOX enzyme expression and activity increase in patients with breast cancer/ breast cancer cells (summarized in Fig. 1). In accordance, in the survey to determine the expression pattern of arachidonic acid metabolizing enzymes in a panel of human epithelial cancer cell lines, it was determined that cyclooxygenase1 (COX-1), 5-lipoxygenase (5-LOX), and 5-lipoxygenase activating protein (FLAP) demonstrated a universal expression in all cells while the expression level of COX-2, 12-lipoxygenase (12-LOX), and 15-LOX revealed to be variable based on the type of cell line. For instance, the 15-LOX transcript was expressed in all types of colon and lung cancer cell lines while among 7 types of breast cancer cell lines (MB231, H2380, SKBR3, T47D, ZR75, MCF-WT, and MCF7-adr), only SKBR3 cells were not able to express 15-LOX also the expression of 15-LOX was not detectable in PC-3 (prostate cancer cells). Furthermore, it was shown that dual inhibition of LOX/ COX enzymes (using 5,8,11,14- eicosatetraenoic acid (ETYA) and general inhibition of LOX enzymes (using Nordihydroguaiaretic acid (NDGA)) caused strong growth inhibition in SKBR3(breast cancer cell line), ZR75 (breast cancer cell line), T47D (breast cancer cell line), and COLO205 (colon cancer cell line) cells. While aspirin (ASA) as a general COX inhibitor, revealed little growth inhibitory effect on the mentioned cell lines indicating that the LOX inhibitors, unlike the COX inhibitors, were more putative in suppressing the growth of

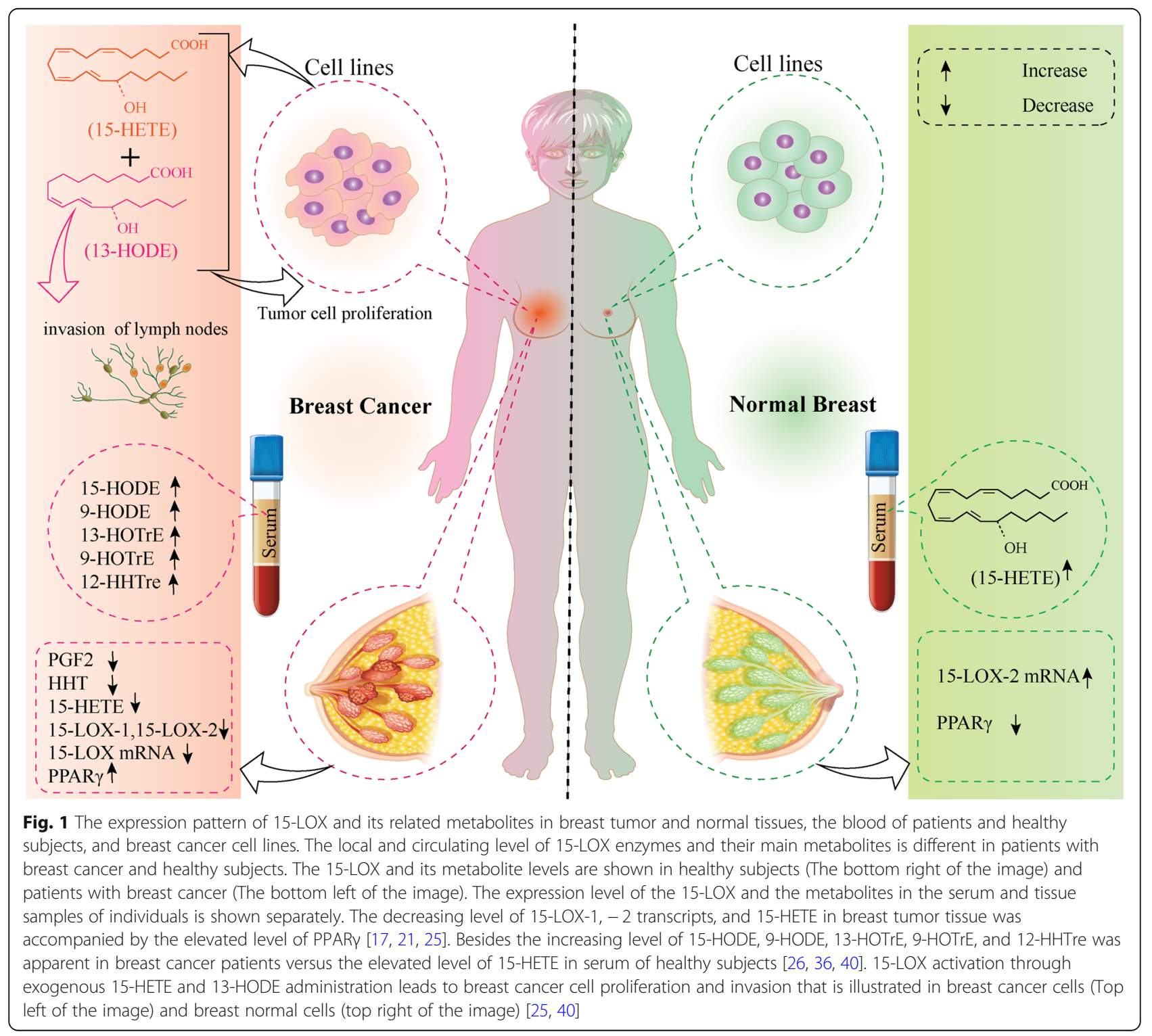


epithelial cancer cells regardless of the expression status of each enzyme [32]. To investigate the status of oxylipins in plasma of 20 patients with breast cancer and the age-matched healthy subjects, it was shown that the significant elevation 13-Hydroxyoctadecadienoic acid (13HODE), 9-Hydroxyoctadecadienoic acid (9-HODE), 13Shydroxy-9Z,11E,15Z-octadecatrienoic acid (13-HOTrE), 9-hydroxy-10E,12Z,15Z-octadecatrienoic acid (9HOTrE), and 12S-hydroxy-5Z,8E,10E-heptadecatrienoic acid (12-HHTrE) was detected in the plasma of the breast cancer patients indicating that the LOX pathway metabolites from linoleic acid and linolenic acid metabolism are mainly up-regulated in breast cancer [33]. The metabolites of normal and tumor breast tissue of 27 patients were quantified using mass spectrometry. In accordance, it was shown that 13-HODE, 15-HETE, 12-Hydroxyeicosatetraenoic acid (12-HETE), 5Hydroxyeicosatetraenoic acid (5-HETE), 5-Oxoeicosatetraenoic acid (5-oxo-ETE), prostaglandin D2 (PGD2), and PGE2 metabolites were expressed in malignant and most of the normal breast tissues, while the only metabolite that its level was correlated with Mib1 scores, aggressive grade, and lymph node metastasis was 13-HODE. In contrast, a negative correlation was observed for PGE2 and PGD2 and aggressive features of breast tumors. To further determine the exact role of 13-HODE and 15-HETE on breast cancer cell growth, cells were exposed to different concentrations of these metabolites and it was shown that MDA-MB-231 and MCF-7 breast cancer cell number and proliferation was increased while PGD2 and PGE2 induced anti-proliferative effects in breast cancer cells. Also, no correlation was detected between the 13-HODE level and those of 15-HETE, 12HETE, PGE2, or PGD2 in normal breast tissue, while the 13-HODE level was highly correlated with the 15HETE level in tumors tissues of patients with 20 Mib1 scores [41]. To clarify the issue, it is worth mentioning that Mib1 is a cell proliferation marker that accounts for the tumor grading system based on summing the tumor differentiation, tumor necrosis, and the Mib1 score [42]. Taken together, activation of 15-LOX-1 and elevation of 13-HODE can stimulate breast cancer proliferation and invasion that possibly might shorten a patient's survival rate [41]. The controversy was observed regarding the expression pattern of 15-LOX level in patients with breast cancer since the mRNA expression of 15-LOX was detected in breast cancer tumor tissues, however, the 15-LOX mRNA level was increased in tumor tissues of some patients and decreased in tumor tissues of other patients compared to the normal breast tissues [43]. Therefore, as with other aspects of tumor growth, the role of each 15-LOX isoform concerning breast cancer growth must be considered independently, given the origin of the tumor and the specific factors produced by the enzymes.

\section{What is the role of 15-LOX products on breast normal cell proliferation and breast tumor cell growth, metastasis, and drug resistance?}

Tumor cell growth is not only dependent on increased cell proliferation but also decreased cell death or apoptosis [44]. In cancer cells, the onset of apoptosis depends on the imbalance between pro-apoptosis and antiapoptosis proteins and the downstream signaling pathways, which often involve caspase or mitochondrial cascades [45]. Evidence from previous studies suggests that 15-LOX may be effective in inducing and promoting cell death in tumors. In accordance, it was shown that in a doxorubicin-resistant breast cell line, 15-LOX-1 was down-regulated remarkably at both mRNA and protein levels compared to the doxorubicin-sensitive cells. Interestingly, the level of 13(S)-HODE showed to be lower in doxorubicin-resistant cells [46]. Based on the results it seems that following acquired resistance to doxorubicin, the 15-LOX-1 mRNA became less stable and no change in a copy number of 15-LOX-1 has occurred. Moreover, inhibition of 15-LOX-1 by (pSUPER-shALOX) shRNA vector in drug-sensitive parental cells were not able to induce doxorubicin-resistant phenotype indicating that other signaling pathways besides 15 -LOX-1 activity might be involved in the induction of drug resistance phenotype. Although 15-LOX-1 over-expression enhanced drug accumulation, cell motility, subG1 arrest and apoptosis induction and, caspase 3/7 increased activity in doxorubicin-resistant MCF-7 cells, the aforementioned results were not obtained following 15-LOX1 over-expression in HeLa doxorubicin-resistant cells [46]. It seems that 15-LOX-1 can interfere with the cell fate and induce apoptosis in a cell-dependent manner. Interestingly, exogenous 13(S)-HODE induced apoptosis and cell cycle arrest in doxorubicin-resistant MCF-7 cells that might be due to the activation of PPAR- $\gamma$. The lack of PPAR- $\gamma$ expression in HeLa doxorubicinresistant cells might be involved in a poor response of these cells to the cytotoxic effect of 13(S)-HODE [46]. Tavakoli-Yaraki et al.; reported that Trichostatin A (TSA) induced cell death and apoptosis in MCF-7 and MDA-MB-231 cells which were accompanied by the induction of apoptosis, cell cycle arrest, and increase in the level of 13(S)-HODE. However, 15-LOX-1 inhibition using PD146176 as a specific, non-competitive 15-LOX inhibitor, attenuated the pro-apoptotic effect of TSA in breast cancer cells also it was shown that 13(S)-HODE synergized with TSA to inhibit breast cancer cell growth and apoptosis. Therefore, based on evidence, it is indicated that the pro-apoptotic effect of TSA on breast 
cancer cell growth might occur through activation of 15LOX-1 and its metabolite [16]. Most studies on the molecular mechanisms underlying 15-LOX-1-induced apoptosis have been implemented on colorectal cancer and the results show that 15 -LOX-1 expression level is decreased in patients with colorectal cancer [25]. Also, the results of experiments on colorectal tumor cells show that the promoter of the $15-\mathrm{LOX}-1$ gene is under the strict control of several processes, including epigenetic processes $[47,48]$. The potential regulatory role of epigenetic processes in controlling 15-LOX expression in breast cancer as well as colorectal cancer has been investigated. In accordance, it was shown that sodium butyrate as a short-chain fatty acid that is suggested to have histone deacetylase inhibitory effects, can regulate the growth of some types of cancer cells such as breast and colon [49]. Based on the evidence provided by Tavakoli-Yaraki et al.; sodium butyrate stimulated the activity of 15-LOX-1 through elevation of 13(S)-HODE level and 15-LOX-1 transcript. Also, it was reported that the rate of apoptosis and the percentages of apoptotic cells induced by sodium butyrate in MCF-7 and MDAMB-468 cells was abrogated following pretreatment of the cells by PD146176. The simultaneous exposure of MCF-7 and MDA-MB-468 cells to the 13(S)-HODE and sodium butyrate was more effective in the induction of breast cancer cell death [50]. Table 2 and Fig. 2 summarize the involvement of 15-LOX in breast cancer cell growth ...

\section{What is the interaction between COX and LOX enzymes with particular reference to 15-LOX?}

As it is well established, improper regulation of the balance between cell proliferation and cell death results in tumor formation and is a hallmark of cancer [44]. Many cellular pathways interfere with the process of cell stagnation, apoptosis, or cell proliferation and it was revealed that LOX products cooperate with different growth factor signaling cascades to stimulate the growth of tumor cells [51]. It was reported that in nude mice under a high-fat diet enriched with linoleic acid, administration of indomethacin (A cyclooxygenase inhibitor) resulted in a higher concentration of prostaglandin $\mathrm{E}$ (PGE), 5-HETE, 12-HETE, and 15-HETE, which in tumors from the control group under high-fat diet enriched with linoleic acid (LA-enriched diet) than in those under diet contains low linoleic acid that was associated with reducing the risk of breast cancer progression in nude mice fed by LA-enriched diet (summarized in Fig. 3) [53]. In support of this evidence, it was shown that the LA-enriched diet can stimulate the MDA-MB435 cells to produce COX and LOX products such as PGE2, 12-HETE, and 15-HETE which was associated with cell invasion. While, inhibition of 12-LOX, but not COX, can abolish eicosanoid metabolites secretion and cell invasion also stimulate the activity of metalloproteinase-9. It can be postulated that the effect of an LA-enriched diet on breast cancer cell growth can be at least partly due to the role of the lipoxygenase enzymes specially 12-LOX [54]. In addition to studies evaluating the role of 15-LOX in the animal model, several studies have examined the above mechanisms at the cellular level, which are demonstrated in Fig. 4. It was shown that inhibition of 15-HETE synthesis using docosahexaenoic acid administration was associated with reduced tumor cell growth and cell proliferation, increased apoptotic cells, and inhibition of tumor-induced angiogenesis [55] (Fig. 4). Also, it was shown that LA isomers suppress the uptake of linoleic acid, the content of cyclic adenosine monophosphate (cAMP) and the activity of extracellular signal-regulated protein kinase 1/2 (Erk1/ 2 ), and production of $13-\mathrm{HODE}$ in steroid receptor-

Table 2 The anti-proliferative effects of 15-LOXand its metabolites in breast cancer cells

\begin{tabular}{|c|c|c|c|}
\hline $\begin{array}{l}\text { Type of 15-LOX enzyme/ me- } \\
\text { tabolites/ other mediators }\end{array}$ & Cell line & Observations & Ref \\
\hline $\begin{array}{l}15-\mathrm{LOX} \\
13(\mathrm{~S})-\mathrm{HODE}\end{array}$ & $\begin{array}{l}\text { doxorubicin-resistant/ } \\
\text { sensitive breast cell line }\end{array}$ & $\begin{array}{l}\text { - } 15-\mathrm{LOX}-1 \text { was down-regulated in doxorubicin-resistant cells vs sensitive cells. } \\
\text { - level of 13(S)-HODE showed to be lower in doxorubicin-resistant cells. } \\
\text { - } 15-\mathrm{LOX}-1 \text { over-expression enhanced drug accumulation, cell motility, subG1 ar- } \\
\text { rest and apoptosis induction, caspase } 3 / 7 \text { increased activity in doxorubicin- } \\
\text { resistant MCF-7 cells. } \\
\text { - exogenous } 13(\mathrm{~S}) \text {-HODE was enough to induce apoptosis and cell cycle arrest } \\
\text { in doxorubicin-resistant MCF-7 through activation of PPAR- } \gamma \text {. }\end{array}$ & {$[46]$} \\
\hline $\begin{array}{l}\text { Trichostatin A } \\
\text { 13(S)-HODE } \\
15-L O X-1 \\
\text { PD146176 }\end{array}$ & MCF-7 and MDA-MB-231 & $\begin{array}{l}\text { - Trichostatin A (TSA) induced cell death, apoptosis, cell cycle arrest and 13(S)- } \\
\text { HODE elevation } \\
\text { - } 15 \text {-LOX-1 suppression diminished the pro-apoptotic effect of TSA in the breast } \\
\text { cancer cells } \\
\text { - } 13(\mathrm{~S}) \text {-HODE synergized with TSA to inhibit breast cancer cell growth and } \\
\text { apoptosis }\end{array}$ & [16] \\
\hline Sodium butyrate (SB) & MCF-7 and MDA-MB-231 & $\begin{array}{l}\text { - The activity of 15-LOX-1 and production of 13(S)-HODE level and15-LOX-1 tran- } \\
\text { script was stimulated by SB. } \\
\text { - Inhibition of 15-LOX-1 eliminated the apoptosis induced by SB in the cells. } \\
\text { - 13(S)-HODE synergized with SB to induce apoptosis in breast cancer cells. }\end{array}$ & [50] \\
\hline
\end{tabular}




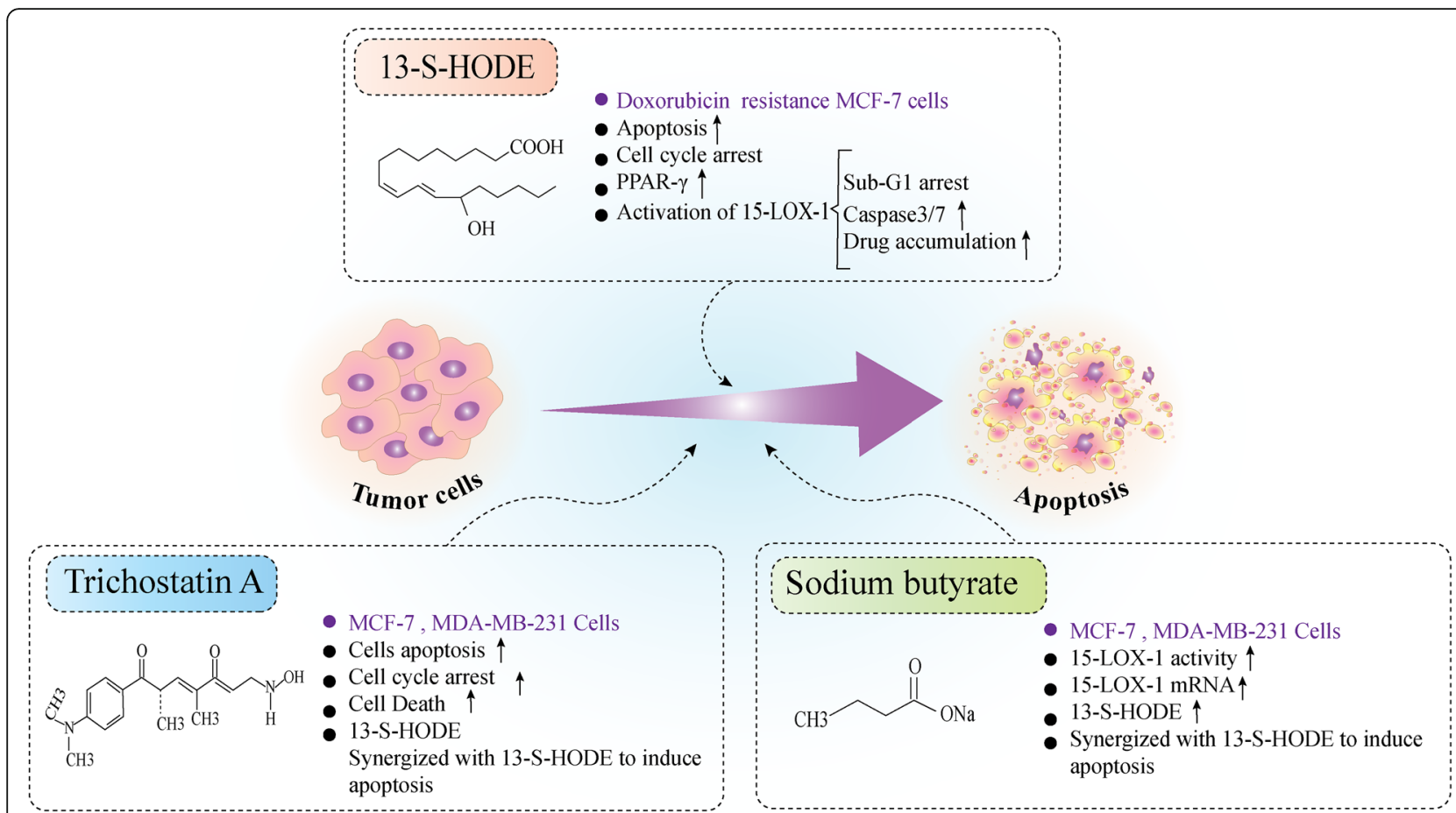

Fig. 2 The pro-apoptotic effects of 15-LOX 1 in breast cancer cells. 15-LOX may mediate the regulation of breast cancer cell death by inducing apoptosis. Activation of 15-LOX and exogenous 13-HODE administration induce apoptosis and cell cycle arrest in doxorubicin-resistant MCF-7 cells [32]. Also, 15-LOX-1 mediates pro-apoptotic effects of Trichostatin A in MCF-7 and MDA-MB-231 cells possibly through elevation of 13-HODE [9]. sodium butyrate induced apoptosis in breast cancer cells through activation of 15-LOX-1 activity and transcript level [43]

negative (SR2) MCF-7 cells possibly in a receptormediated manner. In addition, a small amount of 15(S)HETE was produced in tumor tissue of MCF-7 (SR2) human breast xenografts. The combination of 13-HODE with linoleic acid isomers resulted in the elevation of cAMP level and emphasized the impact of 13-HODE on cAMP level (through activation of adenylate cyclase or suppression of phosphodiesterase) at a pharmacological level however the underlying mechanism needs to be clarified [56] (Fig. 4). It was shown that treatment of MDA-MB-231 cells with conjugated linoleic acid (CLA) (t10, c12-CLA), reduced the level of 15-HETE and 5HETE. Also, incubation of proteins that were extracted from MDA-MB-231 cells with arachidonic acid, resulted in the production of 15- HETE, 12- HETE, and 5-HETE while simultaneous incubation of proteins with arachidonic acid and c9, t11-CLA or t10, c12-CLA did not affect the level of metabolite production. So, it can postulate that 5-, 12- and 15-LOX-2 enzymes have minimum effect on metabolizing c9, t11-CLA or t10, c12CLA in breast cancer. Also, based on the evidence of this study 15-LOX-1 enzyme was not able to metabolize the aforementioned isomers while the linoleic acid is metabolized by 15-LOX-1 and produces 13-HODE [52]. In a study to investigate the impact of CLA supplements on arachidonic acid metabolites (15-, 12-, 5-HETE) and linoleic acid (13-, 9-HODE) levels during induction of breast tumors in rats, it was shown that the 5-HETE, 9HODE, 12-HETE and 13-HODE levels were enhanced while the highest level belonged to the 5-HETE and 15HETE in 7,12-dimethylbenz [a] anthracene (DMBA)-induced tumor group. While the 13-HODE level was dominated in the oil-DMBA-induced tumor group, however; its level was lower in the group treated with CLADMBA $[57,58]$. It was shown that a high CLA diet in pregnant and breastfeeding female rats was associated with a lower risk of mammary tumor induced by chemicals in their offspring. It seems that the concentration of LOX metabolites was effective in this regard. Receiving the CLA supplements was associated with a higher concentration of 15-HETE in serum indicating that the LOX metabolites of arachidonic acid (15-, 12-, 5-HETE) and linoleic acid (HODE) were higher in mammary tumors in groups under the CLA diet. In accordance, there is a competition between CLA and PUFAs that might affect the PUFAs and their LOX metabolites concentrations [59]. It was shown that treatment of MDA-MB435 breast cancer cells with exogenous arachidonic acid resulted in the production of 15(S)-HETE. While in the presence of NDGA (a LOX inhibitor), the exogenous arachidonic acid failed to produce 15(S)-HETE, and the phosphorylation of p38 and mitogen-activated protein 


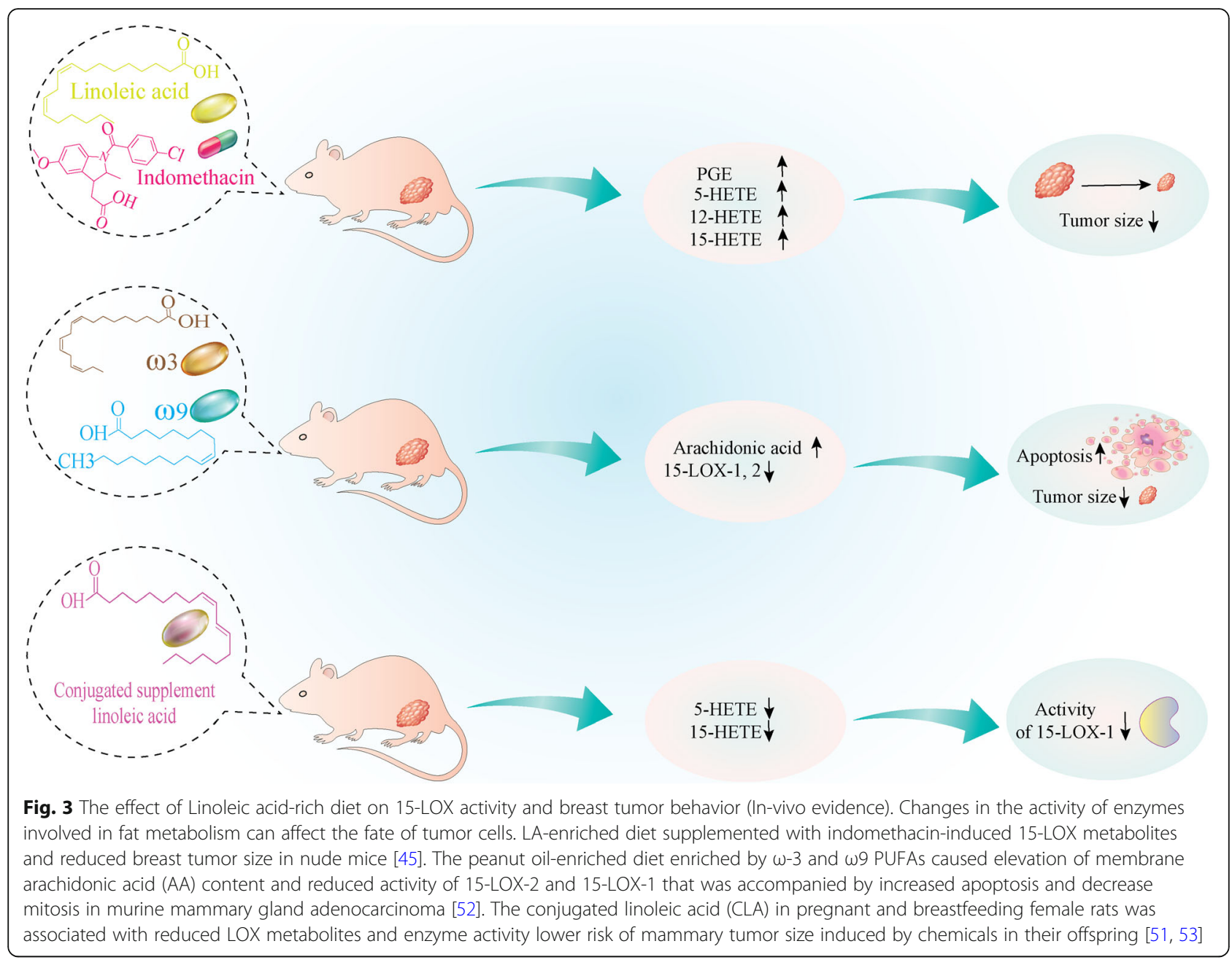

kinase (MAPK) was inhibited (Fig. 4). Interestingly the protein level of 15 -LOX-2 but not 15 -LOX-1 was increased in MDA-MB-435 cells suggesting that 15-LOX2 was responsible to metabolize exogenous arachidonic acid to 15(S)-HETE. Also, treatment of MDA-MB-435 cells with exogenous $15(S)$-HETE resulted in an activation of p38 and MAPK pathway and cell adhesion to type IV collagen indicating the pushing role of $15(S)$ HETE produced by 15 -LOX-2 in activation of signaling pathways related to the cell adhesion to the extracellular matrix [60]. Interestingly it was shown that the circulating level of eicosapentaenoic acid (EPA) inhibits the proliferation of human MCF-7 xenografts that might be mediated by reduction of linoleic acid uptake and 13HODE formation. The lower level of 13-HODE was accompanied by a decrease in cAMP and ERK1/2 phosphorylation in MCF-7 xenografts. In the presence of exogenous 13-HODE to the EPA-containing arterial blood, the uptake of 13-HODE by tumors enhanced, the tumor DNA content increased, and the phosphorylated ERK1/2 was restored [61]. In a study on MCF-7 human breast xenografts, a perfusion system was designed and the tumors were perfused with rat blood that was supplemented with melatonin (MLT), EPA, and CLA promptly and the tumor uptake of linoleic acid and its conversion to $13-\mathrm{HODE}$ and the subsequent release to the blood circulation were monitored. It was revealed that the linoleic acid uptake and 13-HODE generation was suppressed and the phosphorylation of ERK1/2 was significantly reduced following receiving anticancer agents suggesting the association of 13-HODE release rate and ERK1/2 phosphorylation [62]. Also, it was revealed that the peanut oil-enriched diet which is rich in $\omega-3$ and $\omega 9$ PUFAs caused elevation of membrane arachidonic acid content and reduced activity of 15-LOX-2 and 15-LOX-1 that was accompanied by increased apoptosis and decrease mitosis in murine mammary gland adenocarcinoma (Fig. 3). The reduced tumor volume, number of metastasis, and longer survival were detected in the mice group under a peanut oil-enriched diet. In support of this, it was proposed that the reduced severe features of tumors were related to the suppression of 


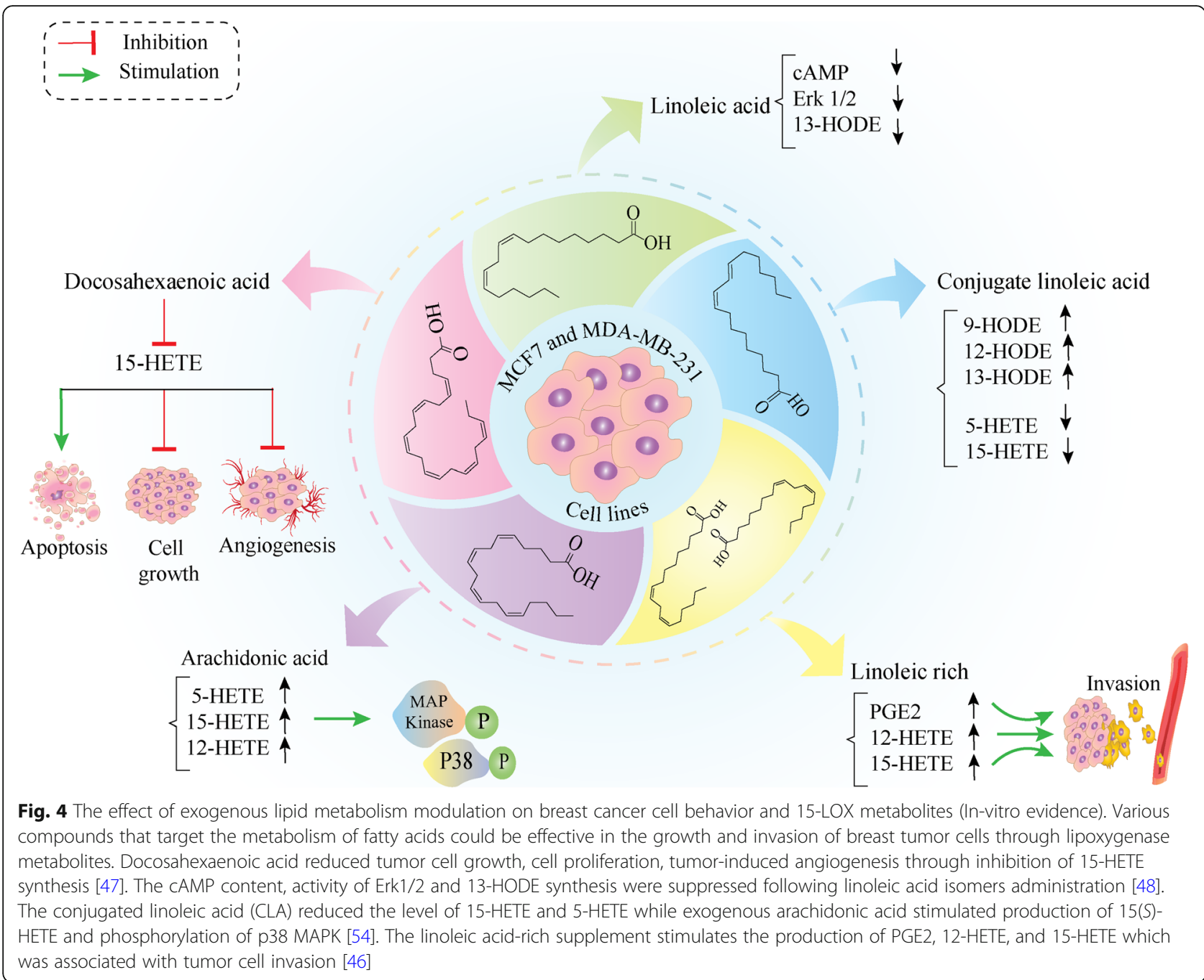

LOXs activity and decrease of pro-tumorigenic eicosanoids such as 15 (S)-HETE [63]. Tables 3 and 4 summarize the tumorigenic effect of 15-LOX and its products in breast cancer tissue and cells.

\section{How anti-cancer drugs act on 15-LOX}

Although it may seem a bit off-topic, interesting studies have been found on the relationship between melatonin, and 13-HODE in breast cancer. It was shown that in human MCF-7 breast cancer xenografts, exposure to constant light stimulates tumor tissue growth. Interestingly, the LA uptake and 13-HODE production in the group that was constantly exposed to the light was increased compared to the control group. The constant light exposure-induced tumor growth can be explained by the suppression of melatonin (MLT) synthesis, increased linoleic acid uptake, and production of 13-HODE [64]. Based on multiple lines of evidence, neurohormone MLT suppresses several human tumor cell growth and metabolism. It seems that the anticancer effect of melatonin occurs in a receptor-mediated manner through inhibition of linoleic acid uptake by tumor cells. It is well documented that linoleic acid is a fatty acid that promotes tumor growth and converts to the 13HODE which has a mitogenic effect. The perfusion of MCF-7 human breast xenografts by melatonin in different time schedules resulted in suppression of linoleic acid uptake and 13-HODE generation by tumors and subsequently decrease the ERK1/2 phosphorylation [62]. Following inhibition of melatonin in dim light at night, the balance among various preventive signaling pathways in cancer is disrupted and resulted in hyperglycemia, hyperinsulinemia, and proliferative activity in the tumor. In addition, during exposure to the light the fatty acid, and linoleic acid uptake, 13-HODE formation, cAMP level, glucose uptake and lactate production increased that was abrogated when exposed to the dark. It was revealed that the control of tumor cell metabolism, aerobic glycolysis, and growth was dependent on the melatonininduced inhibition of 13-HODE formation and 
Table 3 The involvement of 15-LOX and its metabolites in the pro-tumorigenic effects of various conjugated lipid-based diets in breast cancer; in vivo evidences

\begin{tabular}{|c|c|c|c|c|}
\hline $\begin{array}{l}\text { Type of } 15 \text {-LOX en- } \\
\text { zyme/ metabolites } \\
\text { examined }\end{array}$ & $\begin{array}{l}\text { Cell line/Human } \\
\text { tissue type/ } \\
\text { serum }\end{array}$ & Type of intervention & Observations & Ref \\
\hline $\begin{array}{l}\text { PGE, } \\
5 \text {-HETE } \\
\text { 12-HETE } \\
15-\text { HETE }\end{array}$ & $\begin{array}{l}\text { Nude mice tumor } \\
\text { tissue }\end{array}$ & LA-enriched diet & $\begin{array}{l}\text { - Indomethacin caused elevation in the level of PGE, 5-HETE, } \\
12 \text {-HETE, and } 15-\mathrm{HETE} \text { in tumors of the group under LA- } \\
\text { enriched diet Indomethacin might reduce the risk of breast } \\
\text { cancer progression in nude mice fed by LA-rich diet. }\end{array}$ & [53] \\
\hline $\begin{array}{l}\text { LA-derived } \\
\text { prostaglandin E2 } \\
\text { 12-HETE } \\
\text { 15-HETE }\end{array}$ & $\begin{array}{l}\text { MDA-MB-231 cell } \\
\text { solid tumor }\end{array}$ & $\begin{array}{l}\text { Docosahexaenoic acid diet } \\
\text { containing } 4 \% \text { linoleic acid }\end{array}$ & $\begin{array}{l}\text { - Inhibition of 15-HETE synthesis using docosahexaenoic acid } \\
\text { administration caused reduced breast tumor cell growth, sup- } \\
\text { pression of cell proliferation, increased apoptotic cells and in- } \\
\text { hibition of tumor-induced angiogenesis }\end{array}$ & {$[55]$} \\
\hline $\begin{array}{l}5-\mathrm{HETE} \\
9-\mathrm{HODE} \\
12-\mathrm{HETE} \\
13-\mathrm{HODE}\end{array}$ & Rat breast tumors & CLA supplements & $\begin{array}{l}\text { - CLA supplements induced production of 5-HETE, 9-HODE, 12- } \\
\text { HETE and 13-HODE. } \\
\text { - 5-HETE and 15-HETE in 7,12-dimethylbenz [a] anthracene } \\
\text { (DMBA)-induced tumor group. } \\
\text { - CLA- DMBA treated group induced low level of 13-HODE } \\
\text { compared to oil-DMBA-treated group. }\end{array}$ & [58] \\
\hline LOX metabolites & $\begin{array}{l}\text { Pregnant and } \\
\text { breastfeeding } \\
\text { female rats }\end{array}$ & CLA diet & $\begin{array}{l}\text { - LOX metabolites of arachidonic acid (15-, 12-, 5-HETE) and } \\
\text { linoleic acid (HODE) were higher in mammary tumors in } \\
\text { groups under CLA diet. }\end{array}$ & [59] \\
\hline 13-HODE & MCF-7 xenografts & Eicosapentaenoic acid (EPA) & $\begin{array}{l}\text { - EPA inhibit proliferation of human MCF-7 xenografts through } \\
\text { linoleic acid uptake and 13-HODE formation. } \\
\text { - The lower level of } 13-H O D E \text { was accompanied with decrease } \\
\text { in CAMP and ERK1/2 phosphorylation. } \\
\text { - Exogenous } 13-H O D E \text { caused uptake of } 13-H O D E \text { by tumors, } \\
\text { increased the tumor DNA content, restored the phosphory- } \\
\text { lated ERK1/2. }\end{array}$ & [59] \\
\hline $\begin{array}{l}\text { LA } \\
13-H O D E\end{array}$ & $\begin{array}{l}\text { MCF-7 human } \\
\text { breast xenografts }\end{array}$ & $\begin{array}{l}\text { melatonin (MLT), } \\
\text { eicosapentaenoic acid (EPA), } \\
\text { conjugated linoleic acid (CLA) }\end{array}$ & $\begin{array}{l}\text { - Receiving anticancer agents (MLT, EPA, CLA) resulted in } \\
\text { suppression of LA uptake, } 13-\mathrm{HODE} \text { generation and phos- } \\
\text { phorylation of ERK1/2. }\end{array}$ & [62] \\
\hline $\begin{array}{l}\text { Arachidonic acid (AA) } \\
\text { content } \\
15-\text { LOX-1 } \\
15-\text { LOX-2 }\end{array}$ & $\begin{array}{l}\text { Murine mammary } \\
\text { gland } \\
\text { adenocarcinoma. }\end{array}$ & $\begin{array}{l}\text { Peanut oil enriched diet rich in } \\
\omega-3 \text { and } \omega 9 \text { PUFAs }\end{array}$ & $\begin{array}{l}\text { - Peanut oil enriched diet which is rich in } \omega-3 \text { and } \omega 9 \text { PUFAs } \\
\text { caused elevation of membrane AA content, reduced 15-LOX- } \\
2 \text { and 15-LOX-1 activity, increased apoptosis, decrease } \\
\text { mitosis. } \\
\text { - Peanut oil enriched diet reduced tumor volume, number of } \\
\text { metastasis and longer survival of rats. }\end{array}$ & [63] \\
\hline
\end{tabular}

subsequently the activation of protein kinase B (AKT) by 13-HODE. Interestingly, melatonin itself was able to down-regulate phospho-Akt (Ser473) (pAKTs473) and reduce the activity of AKT. The observed effects were diminished in the presence of MT1/MT2 melatonin receptor antagonist S20928. It was concluded that melatonin suppresses linoleic acid uptake, 13-HODE formation, and the Warburg effect in human breast cancer xenografts and 13-HODE play signaling like to activate Warburg effect by AKT activation [65].

\section{How interaction between breast tumor cell- normal cell-tumor microenvironment is influenced by 15-LOX? (The consequent impact on breast tumor cell growth)}

Studies of the last two decades have shown that there are several factors involved in the onset and progression of breast cancer [40]. A considerable number of breast cancer patients experience tumor metastasis and tumor recurrence that leads to premature death. Therefore, recognizing the factors involved in initiating tumor metastasis and the underlying mechanism is helpful in clinical decision-making [66]. Regarding the relevance of the 15-LOX pathway in breast cancer metastasis, it was revealed that the 15-LOX-1 gene induced in MCF-7 cell spheroids when compared with endothelial monolayers. Following enzyme activity inhibition using NDGA, the MCF-7 spheroid-induced circular defects in lymphatic endothelial cell monolayers were remarkably decreased in a dose-dependent manner (Fig. 5). In addition, knockdown of 15-LOX-1 activity using shRNA caused suppression of circular defects formation as well as metastasis to the lymph node in breast xenografted tumors. Based on this study, 15-LOX-1 is involved in mediating tumor cell invasion and lymph node metastasis in breast carcinoma [68]. In support of this, simultaneous inhibition of 15-LOX-1 using baicalein and nuclear factor kappa B (NF-kB) using Bay11-7082 (an inhibitor of $\mathrm{\kappa B}$ kinase (IKK)) caused inhibition of circular chemorepellent-induced defects' (CCID) formation in 
Table 4 The involvement of 15-LOX and its metabolites in the pro-tumorigenic effects of various conjugated lipid-based diets in breast cancer; in vitro evidences

\begin{tabular}{|c|c|c|c|c|}
\hline $\begin{array}{l}\text { Type of } 15 \text {-LOX en- } \\
\text { zyme/ metabolites } \\
\text { examined }\end{array}$ & $\begin{array}{l}\text { Cell line/Human } \\
\text { tissue type/ } \\
\text { serum }\end{array}$ & Type of intervention & Observations & Ref \\
\hline $\begin{array}{l}\text { PGE2 } \\
\text { 12-HETE } \\
\text { 15-HETE }\end{array}$ & MDA-MB-435 cells & LA-enriched supplement & $\begin{array}{l}\text { - linoleic acid-rich supplement stimulate production of PGE2, 12-HETE } \\
\text { and 15-HETE which was associated with cell invasion. } \\
\text { - Inhibition of } 12 \text {-LOX abolish eicosanoid metabolites secretion, cell in- } \\
\text { vasion and activate metalloproteinase-9 }\end{array}$ & [54] \\
\hline $\begin{array}{l}\text { 13-HODE } \\
\text { 15(S)-HETE }\end{array}$ & $\begin{array}{l}\text { Steroid receptor } \\
\text { negative (SR2) } \\
\text { MCF-7 }\end{array}$ & $\begin{array}{l}\text { Linoleic acid isomers/13- } \\
\text { HODE }\end{array}$ & $\begin{array}{l}\text { - Uptake of linoleic acid, the content of cAMP and the activity of Erk1/ } \\
2 \text { and production of 13-HODE were inhibited following linoleic acid } \\
\text { isomers administration. } \\
\text { - linoleic acid isomers caused production of 15(S)-HETE in tumor tissue } \\
\text { of MCF-7 (SR2) human breast xenografts. } \\
\text { - 13-HODE synergize with linoleic acid to elevate CAMP level. }\end{array}$ & [56] \\
\hline $\begin{array}{l}\text { 15-HETE } \\
5 \text {-HETE } \\
\text { 12- HETE }\end{array}$ & MDA-MB-231 & $\begin{array}{l}\text { Conjugated linoleic acid } \\
\text { (CLA) }\end{array}$ & $\begin{array}{l}\text { - CLA (t10, c12-CLA) reduced 15-HETE and 5-HETE level. } \\
\text { - Arachidonic acid caused production of 15- HETE, 12- HETE and 5- } \\
\text { HETE while incubated with cell extracted proteins. } \\
\text {-5-, 12- and 15-LOX-2 have minimum effect on metabolizing c9, t11- } \\
\text { CLA or t10, c12-CLA in breast cancer. } \\
\text { - 15-LOX-1 was not able to metabolize c9, t11-CLA or t10, C12-CLA } \\
\text { isomers. }\end{array}$ & [52] \\
\hline $\begin{array}{l}\text { 15(S)-HETE } \\
15-\text { LOX-1 } \\
15-\text { LOX-2 }\end{array}$ & MDA-MB-435 & $\begin{array}{l}\text { Exogenous arachidonic } \\
\text { acid/ exogenous 15(S)- } \\
\text { HETE }\end{array}$ & $\begin{array}{l}\text { - Exogenous arachidonic acid results in the production of } 15(\mathrm{~S})-\mathrm{HETE} \\
\text { and phosphorylation of p38 MAPK that were abrogated following } \\
\text { LOX inhibition. } \\
\text { - Exogenous arachidonic acid induced protein expression of 15-LOX-2 } \\
\text { but not 15-LOX-1. } \\
\text { - Exogenous } 15(S) \text {-HETE activate p38 MAPK pathway and cell adhesion } \\
\text { to type IV collagen }\end{array}$ & {$[60]$} \\
\hline
\end{tabular}

MCF-7 cell spheroids. While attaching to the lymphendothelial cell monolayers, CCID is considered as a tumor intravasation process and it seems that generation of 12 (S)-HETE by 15 -LOX-1 under NF- $\mathrm{kB}$ regulation can facilitate CCID and attachment of breast cancer cells to the lymph-endothelial cells [67]. In addition, exposure of breast cancer cells to the EPA resulted in an increased expression level of E-cadherin, while treatment of the cells with gamma linoleic acid (GLA) did not affect Ecadherin level. However, both GLA or EPA treatments caused elevation of 15(S)-HETE and 13(S)-HODE level in MCF-7 cells, and a higher level of 13(S)-HODE was observed when compared to 15(S)-HETE although the reduced expression of E-cadherin in breast cells seemed to be dependent to the ratio of 15 -LOX-1 metabolites [69]. The proteome study in myeloid-derived suppressor cells (MDSCs) in response to metastatic breast tumors, demonstrated that in MDSCs the selective expression of lipid metabolic pathway occurs. It was found that in MDSCs from metastatic 4 T1 tumors, the 15-LOX-1 was a positive activator of cAMP Response Element-Binding Protein (CREB) which is a transcription factor and is involved in the biological process in MDSCs [70]. In another study, it was shown that while bovine mammary endothelial cells (BMEC) were exposed to Streptococcus uberis no effect was detected on 15-LOX-1 metabolite levels, while exposure of bovine monocytes to Streptococcus uberis resulted in the production of 13-
Hydroperoxyoctadeca-cis-9, trans-11-dienoic acid (13HPODE) and 13-HODE during mastitis. Interestingly, treatment of BMEC with 13-HPODE reduced endothelial barrier integrity and accelerate apoptosis while cotreatment with antioxidants, reverses the previously seen effects [71]. It was found that 15-LOX-1 suppression using novel purine-pyrazole hybrids which contain thiazoles, thiazolidinones and rhodanines reduced the rate of viable MCF-7 cells and proposed to act as an anticancer compound in breast cancer [34, 72, 73]. It was shown that the exogenous arachidonic acid was metabolized in TMT-081 rat mammary tumor cell line and the range of eicosanoids metabolites including lipoxygenase and cyclooxygenase metabolites were produced. In accordance, it was observed that the DNA synthesis was stimulated in response to the 15-HETE and LOX inhibition using NDGA and esculetin that resulted in TMT081 cell growth suppression [74]. It was shown that incubation of BT-20 cells (triple-negative breast cancer cells) with Transforming growth factor-alpha (TGF- $\alpha$ ) and A23187, a mobile ion-carrier, caused 13-HODE formation which was dependent on the Epidermal growth factor (EGF) / TGF- $\alpha$. While by suppression LOX activity, the TGF- $\alpha$-dependent generation of 13-HODE and stimulation of DNA synthesis was abrogated. The findings indicated that LOX activity and 13-HODE production are involved in transferring the mitogenic signals that transferred from EGF/TGF- $\alpha$ in the cell surface to 


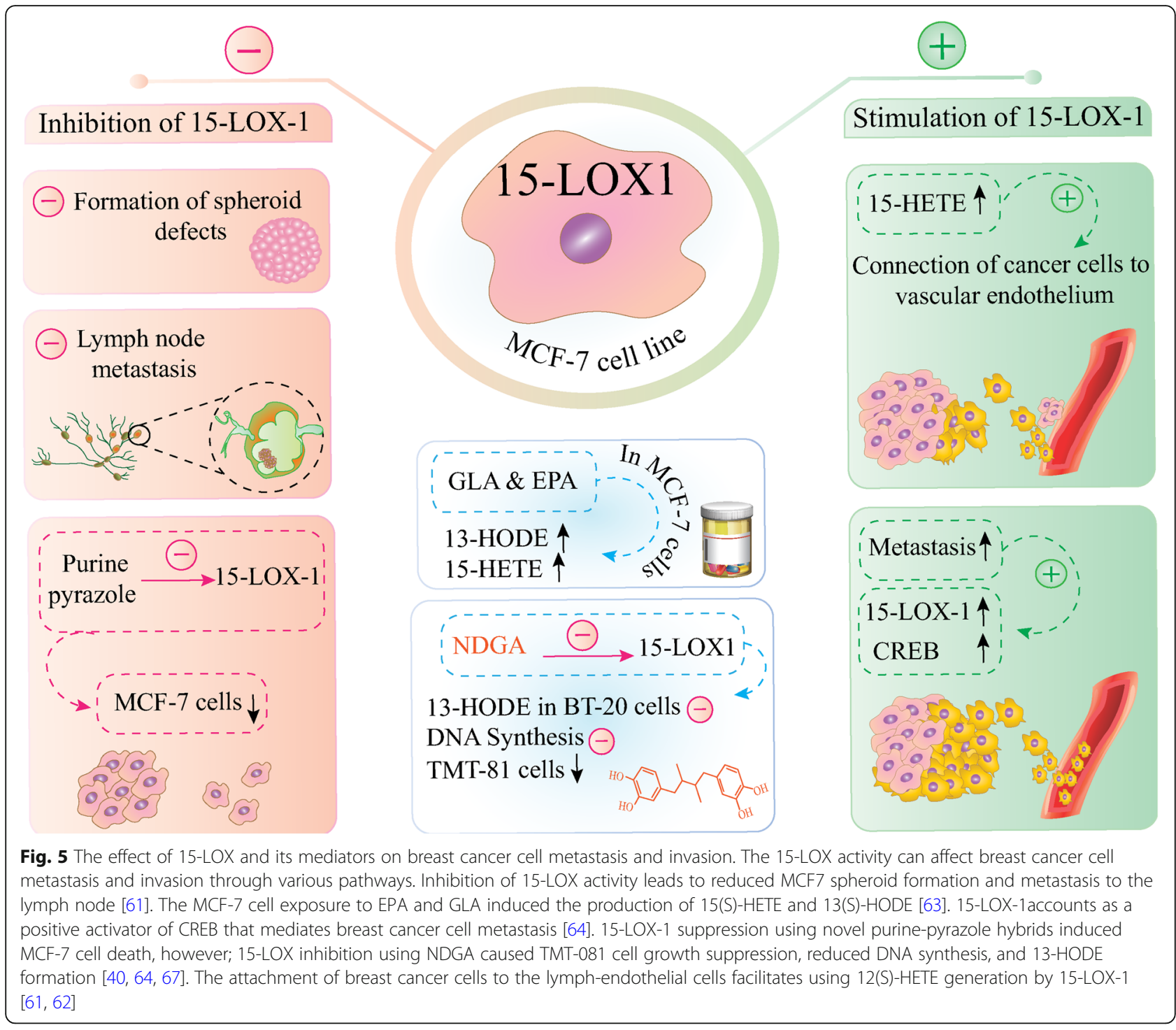

the cell nucleus in breast cancer [75]. The relation of 15LOX and its products with breast cancer metastasis and invasion is summarized in Table 5 .

\section{How are 15-LOX and oxidative stress connected to regulate breast cancer cell growth?}

It is taken for granted that increased lipid peroxidation and oxidative stress account as crucial risk factors for breast cancer incidence, development, and progression [76]. On the other hand, tumor cell fate, growth, invasion and, death are influenced by lipid metabolism, peroxidation, and level of saturation [77]. As a consequence of aerobic metabolism, reactive oxygen species (ROS) are continually generated and transformed in the normal and tumor cells that are involved in various cell functions including cell proliferation and death. Therefore, maintaining redox balance by increasing antioxidant capacity and reducing the production of ROS is essential for the survival of tumor cells [78]. In support of this, the catalytic activity of LOX enzymes leads to the production of lipid peroxides that are involved in different cell signaling events regulating tumor cell growth or death. Notably, overproduction of lipid peroxides alongside iron accumulation can trigger ferroptosis which accounts for a type of programmed cell death [79]. It was shown that upon ROS stress, activation of 12-LOX induced ferroptosis in tumor cells through overproduction of lipid peroxides [7]. The regulatory role of 15-LOX in inducing the above cell death seems more important and interesting. It was shown that glutathione peroxidase 4 (GPX4) as a protective enzyme against lipid peroxidation as well as 15-LOX can induce nuclear factor erythroid-2 like 2 (NFE2L2) (Nrf2) as a regulator of antioxidant response in tumor cells that suppress ferroptosis and contributes to tumor cell chemoresistance [79]. Although the role of 15 -LOX and its metabolites in stimulating 
Table 5 The effects of 15-LOX and its metabolites in breast cancer metastasis and invasion

\begin{tabular}{|c|c|c|c|c|}
\hline $\begin{array}{l}\text { Type of } 15 \text {-LOX en- } \\
\text { zyme/ metabolites } \\
\text { examined }\end{array}$ & $\begin{array}{l}\text { Cell line/Human tissue } \\
\text { type/serum }\end{array}$ & $\begin{array}{l}\text { Type of } \\
\text { treatment }\end{array}$ & Observations & Ref \\
\hline 15-LOX-1 & $\begin{array}{l}\text { MCF7/ endothelial } \\
\text { monolayers }\end{array}$ & $\begin{array}{l}\text { 15-LOX-1 } \\
\text { activation } \\
15-\text { LOX-1 } \\
\text { inhibition }\end{array}$ & $\begin{array}{l}\text {-15-LOX-1 gene activation induced in MCF7 cell spheroids. } \\
\text { - } 15 \text {-LOX-1 inhibition/knock-down leads to MCF7 spheroid-induced } \\
\text { circular defects in lymphatic endothelial cell monolayers decrease. } \\
\text { - } 15 \text {-LOX-1 knock-down suppress formation of circular defects and } \\
\text { metastasis to the lymph node in breast xenograft tumors. }\end{array}$ & [68] \\
\hline $\begin{array}{l}\text { 15-LOX-1 } \\
\text { 12(S)-HETE }\end{array}$ & MCF-7 & $\begin{array}{l}\text { 15-LOX-1 } \\
\text { inhibition }\end{array}$ & $\begin{array}{l}\text { - 15-LOX-1 inhibition (baicalein) and NF-kB (Bay11-7082) caused in- } \\
\text { hibition of circular chemo repellent-induced defects' (CCID) for- } \\
\text { mation in MCF-7 cell spheroids. } \\
\cdot \text { 12(S)-HETE generation by 15-LOX-1 under NF-kB facilitate CCID } \\
\text { and attachment of breast cancer cells to the lymph-endothelial } \\
\text { cells. }\end{array}$ & {$[67]$} \\
\hline 15(S)-HETE 13(S)-HODE & MCF-7 & $\begin{array}{l}\text { Exposure to } \\
\text { eicosapentaenoic } \\
\text { (EPA), } \\
\text { gamma linoleic } \\
\text { acid (GLA) }\end{array}$ & $\begin{array}{l}\text { - EPA treatment caused increased expression level of E-cadherin } \\
\text { while GLA treatment had no effect. } \\
\text { - GLA or EPA treatment caused elevation of 15(S)-HETE and 13(S)- } \\
\text { HODE level }\end{array}$ & [69] \\
\hline 15-LOX-1 & $\begin{array}{l}\text { Myeloid derived suppressor } \\
\text { cells (MDSCs), } \\
\text { metastatic breast tumors }\end{array}$ & & $\begin{array}{l}\text { - In MDSCs from metastatic 4T1 tumors, 15-LOX-1 was a positive } \\
\text { activator of CREB. }\end{array}$ & [70] \\
\hline 13-HPODE 13-HODE & $\begin{array}{l}\text { Bovine mammary } \\
\text { endothelial cells (BMEC), } \\
\text { bovine monocytes }\end{array}$ & $\begin{array}{l}\text { Streptococcus } \\
\text { uberis }\end{array}$ & $\begin{array}{l}\text { - } 15 \text {-LOX-1 metabolite levels remained unchanged in BMEC ex- } \\
\text { posed to Streptococcus uberis. } \\
.13-H P O D E \text { and } 13-H O D E \text { produced in bovine monocytes exposed } \\
\text { to Streptococcus uberis. } \\
\text { - BMEC treatment with 13-HPODE reduced endothelial barrier in- } \\
\text { tegrity, accelerate apoptosis while the effects reversed in CO- } \\
\text { treatment with antioxidant. }\end{array}$ & [71] \\
\hline 15-LOX-1 & MCF-7 & $\begin{array}{l}\text { purine-pyrazole } \\
\text { hybrids }\end{array}$ & $\begin{array}{l}\text { - } 15 \text {-LOX-1 suppression using purine-pyrazole hybrids reduced the } \\
\text { rate of viable MCF-7 cells }\end{array}$ & [34] \\
\hline 15-HETE & $\begin{array}{l}\text { TMT-081 rat mammary } \\
\text { tumor cell line }\end{array}$ & $\begin{array}{l}\text { Exogenous } \\
\text { arachidonic acid/ } \\
\text { to } 15-\mathrm{HETE}\end{array}$ & $\begin{array}{l}\text { - } 15 \text {-HETE stimulate DNA synthesis in TMT-081 cells. } \\
\text { - LOX inhibition using NDGA and esculetin resulted in TMT-081 cell } \\
\text { growth suppression. } \\
\text { - Exogenous arachidonic acid induced production of eicosanoids } \\
\text { metabolites in TMT-081. }\end{array}$ & [74] \\
\hline $\begin{array}{l}\text { 13-HODE } \\
\text { LOX }\end{array}$ & BT-20 cells & TGF alpha A23187 & $\begin{array}{l}\text { - TGF alpha and A23187 caused } 13-\mathrm{HODE} \text { formation in BT-20 cells. } \\
\text { - LOX activity suppression reduced } 13-\mathrm{HODE} \text { formation and DNA } \\
\text { synthesis. } \\
\text { - LOX activity and } 13-\mathrm{HODE} \text { production are involved in transferring } \\
\text { the mitogenic signals in breast cancer cell. }\end{array}$ & [75] \\
\hline
\end{tabular}

various intracellular pathways leading to the regulation of oxidative stress and tumor cell fate can be extensive, the evidence in breast cancer is very limited. In the most relevant study, Xinghan Wu et all demonstrated that inhibition of Glycogen synthase kinase-3 $\beta$ (GSK-3 $\beta$ ) resulted in decreased ROS and malondialdehyde (MDA) level through activation of GPX4 and inhibition of 15LOX that blocked ferroptosis in MCF-7, MDA-MB-231 breast cancer cells. It was shown that GSK-3 $\beta$ is a positive regulatory enzyme to promote cancer cell proliferation and survival and based on shreds of evidence, 15LOX might be served by GSK-3 $\beta$ as a downstream mediator to regulate feroptosis in breast tumor cells [80]. On the other hand, it was shown that sodium butyrate as a short-chain fatty acid-induced 15-LOX gene expression and activity in breast cancer cells through elevation of 13-HODE [50]. The ability of sodium butyrate to trigger cell cycle arrest and apoptosis through the generation of ROS and reduced mitochondrial membrane potential $(\Delta \psi \mathrm{m})$ in breast cancer cells [81] and its positive regulatory effect on 15-LOX may suggest that 15-LOX is contributed to the production of ROS in sodium butyrateelicited apoptosis (Data is illustrated in Fig. 6). However, the significance of 15-LOX in the context of oxidative stress and redox biology in breast cancer pathogenesis is still emerging and needs to be clarified by more mechanistic studies.

\section{What are the clinical implications of 15-LOX inhibition or activation in breast cancer treatment?}

The use of small molecular inhibitors that can inhibit key enzymes in the metabolic pathway is one of the main and important strategies in targeted cancer therapy 


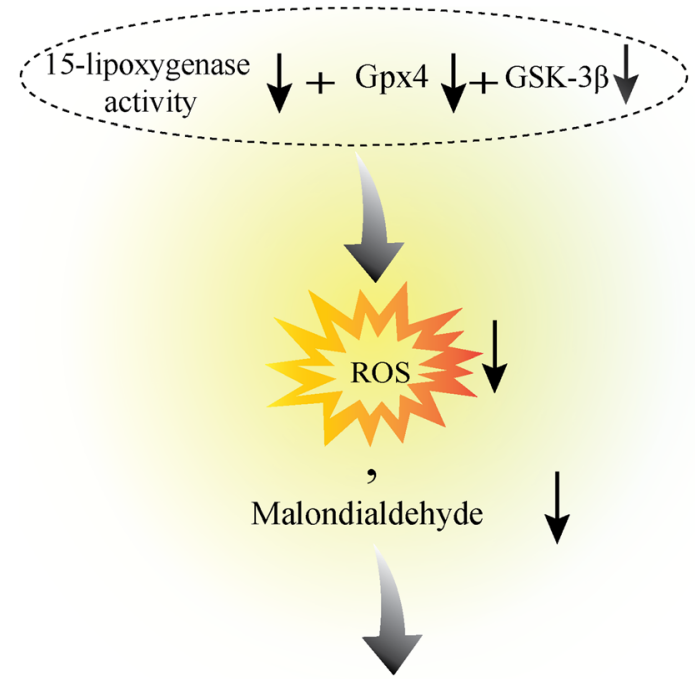

Ferroptosis Induced by erastin

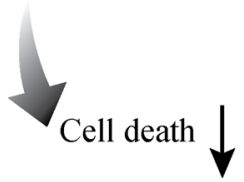

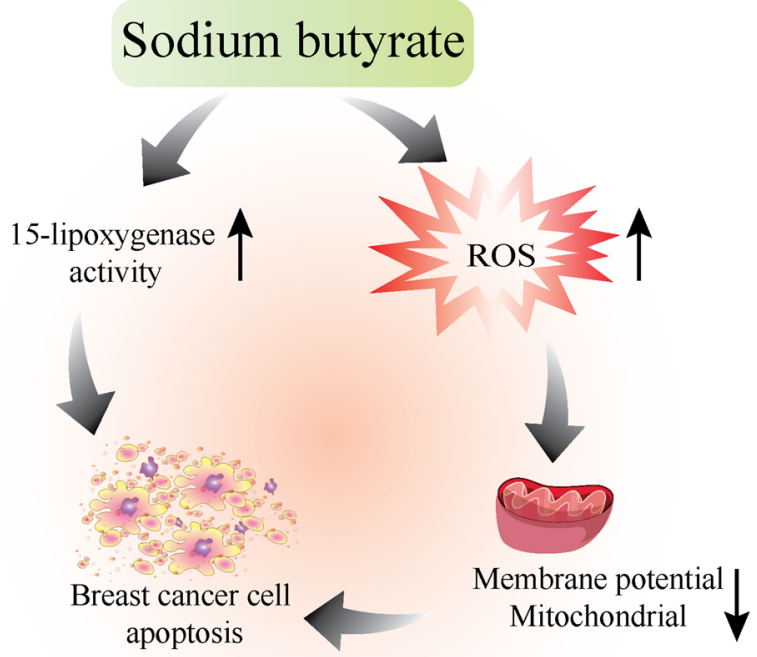

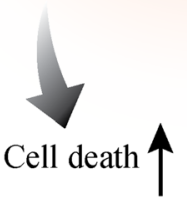

Fig. 6 The relevance of 15-LOX and the oxidative stress in breast cancer cell growth. The reduction in the expression level of 15-LOX-1 is associated with a decrease in the level of ROS and reduced breast cancer cell death [74]. Also, 15-LOX-1 activation-induced breast cancer cell apoptosis might occur through the generation of ROS [75]

[82]. Notably, interesting studies have been performed on small molecular compounds capable of inhibiting the 15-LOX, which can be considered as potent chemopreventive compounds in cancer prevention and treatment [83]. One of the well-documented ones is quercetin, which is a natural flavone with the ability to regulate cell cycle distribution, apoptosis, angiogenesis, and 15-LOX inhibitory activity [84]. It is demonstrated that quercetin sensitizes breast cancer cells to death and inhibits angiogenesis and EMT process, however, the efficiency of the quercetin-rich diet in breast cancer treatment needs to be clarified by further clinical trials [85]. Moreover, it was revealed that rhein and aloe-emodin, as polymethoxylated flavonoids which are extracted from orange peel inhibited soybean 15-LOX potently as well as breast cancer angiogenesis and growth [86]. On the other hand, $\Delta 9$-tetrahydrocannabinol $(\Delta 9$-THC) [87], as an active component of Cannabis Sativa (C. sativa) and a member of phytocannabinoid family, can directly inhibit 15-LOX and suppress breast cancer cell proliferation [88]. The selective inhibitory effect of other derivatives of phytocannabinoids such as cannabidiol (CBD) on 15-LOX activity has been proven previously and invivo evidence revealed the potency of CBD to reduce breast cancer growth $[88,89]$. The ortho-hydroxy analogs of pyrazoles have been shown to have an inhibitory effect on 15-LOX also the potential to inhibit breast cancer cell proliferation [90]. Taken together, the mentioned 15-LOX inhibitors showed anti-proliferative and cytotoxic effects on breast cancer cells through suppression of 15-LOX activity, however, the therapeutic use of these compounds in humans has not yet been addressed and requires further investigation at the clinical trial level. Evidence also has shown that 15-LOX-1 overexpression as well as exposure to the exogenous 13(S)HODE enhanced drug accumulation, cell motility, subG1 arrest, apoptosis induction and, caspase 3/7 increased activity in doxorubicin-resistant MCF-7 cells, indicating the possibility of 15-LOX pathway involvement in the response of breast cancer cells to the doxorubicin treatment [46].

\section{Conclusion}

This review attempts to highlight the expression pattern of 15-LOX enzymes and their metabolites in breast tumors and normal tissues as well as their significance in breast cancer cell growth, death, invasion, and metastasis. Studies show the dual role of the LOX pathway in the pathogenesis of breast cancer. Both decreased and increased expression of LOX enzymes were shown in breast tumor tissue compared to healthy breast tissues. Among the studies performed, it seems that 15-LOX-2 and 15-S-HETE showed a significant reduction in breast tumor tissue, which was adjusted by PPAR- $\gamma$ activity. 
Based on the study of Hong et al., the expression pattern of 15-LOX isomers and metabolites in different types of breast cancer cells can be different which can explain the differential expression of these enzymes in different patients with breast cancer. Since in the patients studied more attention was paid to the degree of tumor severity, and disease severity and the molecular nature of breast tumor cells in these patients was not considered. On the other hand, the LOX enzymatic pathway is an important metabolic pathway for the normal life of healthy cells that can be affected by different conditions of growth, nutrition, and overall homeostasis of cells. Most of the results regarding the role of 15-LOX in inducing apoptosis in breast cancer cells indicated the mediating role of this enzyme or the synergistic effect of the metabolites of 15-LOX in inducing death pathways by other compounds. However, there was stronger evidence for the tumorigenic role of the 15-LOX pathway in breast tumor progression. It can be postulated that 15-LOX metabolites regulate breast tumor cell growth through elevation of cAMP level, phosphorylation of p38MAPK, phosphorylation of ERK1/2, and increased tumor DNA content; however, the type of fat diet that the cells were exposed to, was decisive in the type of response they exhibited. It seems that 15-LOX-1 and its metabolites (15(S)-HETE 13(S)-HODE) were effective in breast cancer cell spheroids formation, metastasis to the lymph node, CREB activation, and transferring the mitogenic signals of TGF- $\alpha$. Taken together, the relevance of 15-LOX enzymes and metabolites in breast tumor cell growth has been proven broadly; however, the exact role of this pathway on breast cancer pathogenesis remains to be determined, and future studies are warranted.

\section{Abbreviations}

ALA: Alpha-linolenic acid; LA: Linoleic acid; DHA: Docosahexaenoic acid; AA: Arachidonic acid (AA); COX: Cyclooxygenase; PG: Prostaglandin; PGE: Prostaglandin E; TX: Thromboxane; TXA2: Thromboxane A2;

CYP: Cytochrome P450; EETs: Epoxyeicosatrienoic acids; LT: Leukotrienes; LOX: lipoxygenase; HpETE: Hydroperoxyeicosatetraenoic acid; HETE: Hydroxyeicosatetraenoic acid; 13-HODE: 13-Hydroxyoctadecadienoic acid; 15-LOX: 15-lipoxygenase-15; 15-LOX-1: 15-lipoxygenase type 1; 15-LOX2: 15- lipoxygenase type 2; A549 cell line: Adenocarcinoma human alveolar basal epithelial cells; Caco2 cell line: Human colorectal adenocarcinoma cells; IL4: Interleukin 4; IL13: Interleukin-13; STAT6: Signal transducer and activator of transcription 6; NO: Nitric oxide; 15-S-HETE: 15(S)hydroperoxyeicosatetraenoic acid; 13(S)-HODE: 3(S)-hydroxy-9Z,11Eoctadecadienoic acid; NSCLC: Non-Small Cell Lung Cancer; COX2: Cyclooxygenase-2; CK19: Cytokeratin 19; ER: Estrogen receptor; PPAR$\gamma$ : Peroxisome proliferator- activated receptor gamma; PGE2: Prostaglandin E2; 6-k-PGF1a: 6-keto-Prostaglandin F1 Alpha; PGF 2 : prostaglandin F2a; HHT: Heptadecatrienoic acid; 15-HETE: 15-Hydroxyeicosatetraenoic acid; DHKPG: 13,14-dihydro-15-keto-prostaglandin; 15-L-(S)-HPETE: 15-L-(S)hydroperoxyeicosatetraenoic acid; COX-1: Cyclooxygenase-; 5-LOX: 5lipoxygenase; FLAP: 5-lipoxygenase activating protein; 12-LOX: 12lipoxygenase; ETYA: 5,8,11,14-eicosatetraynoic acid;

NDGA: Nordihydroguaiaretic acid; ASA: Aspirin; 9-HODE: 9Hydroxyoctadecadienoic acid; 13-HOTrE: 13S-hydroxy-9Z,11E,15Z-

octadecatrienoic acid; 9-HOTrE: 9-hydroxy-10E,12Z,15Z-octadecatrienoic acid; 12-HHTrE: 12S-hydroxy-5Z,8E,10E-heptadecatrienoic acid; 12-HETE: 12-

Hydroxyeicosatetraenoic acid; 5-HETE: 5-Hydroxyeicosatetraenoic acid; 5-oxo-
ETE: 5-Oxo-eicosatetraenoic acid; TSA: Trichostatin A; LA-enriched diet: Highfat diet enriched with linoleic acid; CAMP: Cyclic adenosine monophosphate; Erk1/2: Extracellular signal-regulated protein kinase 1/2; SR2: Steroid receptor negative; CLA: Conjugated linoleic acid; DMBA: 7,12-dimethylbenz [a]anthracene; PUFAs: Polyunsaturated fatty acids; MAPK: Mitogen-activated protein kinase; EPA: Eicosapentaenoic acid; MLT: Melatonin; AKT: Protein kinase B; pAKTs473: Phospho-Akt (Ser473); NF-kB: Nuclear factor kappa B; CCID: Chemo repellent-induced defects; GLA: Gamma linoleic acid; MDSCs: Myeloid derived suppressor cells; CREB: CAMP Response ElementBinding Protein; BMEC: Bovine mammary endothelial cells; 13-HPODE: 13Hydroperoxyoctadeca-cis-9, trans-11-dienoic acid; TGF-a: Transforming growth factor alpha; EGF: Epidermal growth factor; ROS: Reactive oxygen species; GPX4: Glutathione peroxidase 4 (GPX4); NFE2L2: nuclear factor

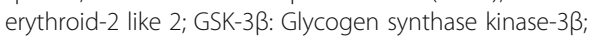

MDA: Malondialdehyde; $\Delta \psi \mathrm{m}$ : mitochondrial membrane potential; $\Delta 9$ -

THC: $\Delta 9$-tetrahydrocannabinol; C. sativa: Cannabis Sativa; CBD: Cannabidiol

\section{Acknowledgements}

Not applicable.

\section{Authors' contributions}

M.A.V performed data collection and investigation and contributed in preparing tables and writing - original draft, B. S and A.R.E, contributed in data collection and investigation, S.S.GH and M. R prepared figures, V. S performed conceptualization and validate data and M.T.Y designed the study, supervised the project and prepared the manuscript.All authors read and approved the final manuscript.

\section{Funding}

This work was financially supported by Iran University of Medical Sciences (Grant Number: 93-02-30-24469). The funding body played no role in the design of the study, collection, interpretation and in writing a manuscript.

\section{Availability of data and materials}

All data generated or analyzed during this study are included in this published article.

\section{Declarations}

Consent for publication

Not applicable.

\section{Competing interests}

The authors declare that there is no conflict of interest.

\section{Author details}

'Department of Biochemistry, School of Medicine, Iran University of Medical Sciences, P.O. Box: 1449614535, Tehran, Iran. ${ }^{2}$ Department of Biochemistry, Faculty of Pharmacy, Isfahan University of Medical Sciences, Isfahan, Iran. ${ }^{3}$ Department of Microbiology, School of Medicine, Golestan University of Medical Sciences, Gorgan, Iran. ${ }^{4}$ Department of Virology, School of Public Health, Tehran University of Medical Sciences, Tehran, Iran.

Received: 30 August 2021 Accepted: 11 November 2021

Published online: 27 November 2021

\section{References}

1. Wang B, Wu L, Chen J, Dong L, Chen C, Wen Z, et al. Metabolism pathways of arachidonic acids: mechanisms and potential therapeutic targets. Signal Transduct Target Ther. 2021;6(1):94. https://doi.org/10.1038/s41392-02000443-w.

2. Dubois RN, Abramson SB, Crofford L, Gupta RA, Simon LS, Van De Putte LB, et al. Cyclooxygenase in biology and disease. FASEB J. 1998;12(12):1063-73. https://doi.org/10.1096/fasebj.12.12.1063.

3. Samuelsson B. Prostaglandins, thromboxanes, and leukotrienes: formation and biological roles. Harvey Lect. 1979;75:1-40.

4. Rizos AL, Sargenti CJ, Jeste DV. Psychotropic drug interactions in the patient with late-onset depression or psychosis. Part 2. Psychiatr Clin North Am. 1988;11(1):253-77. https://doi.org/10.1016/50193-953X(18)30527-6.

5. Capdevila J, Marnett L, Chacos N, Prough RA, Estabrook RW. Cytochrome P450-dependent oxygenation of arachidonic acid to hydroxyicosatetraenoic 
acids. Proc Natl Acad Sci U S A. 1982;79(3):767-70. https://doi.org/10.1073/ pnas.79.3.767.

6. Xu X, Zhang XA, Wang DW. The roles of CYP450 epoxygenases and metabolites, epoxyeicosatrienoic acids, in cardiovascular and malignant diseases. Adv Drug Deliv Rev. 2011;63(8):597-609. https://doi.org/10.1016/j.a ddr.2011.03.006

7. Zheng Z, Li Y, Jin G, Huang T, Zou M, Duan S. The biological role of arachidonic acid 12-lipoxygenase (ALOX12) in various human diseases. Biomed Pharmacother. 2020;129:110354. https://doi.org/10.1016/j.biopha.202 0.110354 .

8. Andreou A, Feussner I. Lipoxygenases - Structure and reaction mechanism. Phytochemistry. 2009;70(13-14):1504-10. https://doi.org/10.1016/j. phytochem.2009.05.008.

9. Liavonchanka A, Feussner I. Lipoxygenases: occurrence, functions and catalysis. J Plant Physiol. 2006;163(3):348-57. https://doi.org/10.1016/j.jplph.2 005.11.006.

10. Feussner I, Wasternack C. The lipoxygenase pathway. Annu Rev Plant Biol. 2002;53(1):275-97. https://doi.org/10.1146/annurev.arplant.53.100301.135248.

11. Brinckmann R, Topp MS, Zalán I, Heydeck D, Ludwig P, Kühn H, et al. Regulation of 15-lipoxygenase expression in lung epithelial cells by interleukin-4. Biochem J. 1996;318(Pt 1):305-12. https://doi.org/10.1042/bj31 80305.

12. Heydeck D, Thomas L, Schnurr K, Trebus F, Thierfelder WE, Ihle JN, et al. Interleukin-4 and -13 induce upregulation of the murine macrophage 12/ 15-lipoxygenase activity: evidence for the involvement of transcription factor STAT6. Blood. 1998;92(7):2503-10. https://doi.org/10.1182/blood.V92. 7.2503.

13. Zuo X, Morris JS, Shureiqi I. Chromatin modification requirements for 15lipoxygenase-1 transcriptional reactivation in colon cancer cells. J Biol Chem. 2008;283(46):31341-7. https://doi.org/10.1074/jbc.M803729200.

14. Hsi LC, Kundu S, Palomo J, Xu B, Ficco R, Vogelbaum MA, et al. Silencing IL13Ra2 promotes glioblastoma cell death via endogenous signaling. Mol Cancer Ther. 2011;10(7):1149-60. https://doi.org/10.1158/1535-7163.MCT-1 0-1064.

15. Dhabal S, Das P, Biswas P, Kumari P, Yakubenko VP, Kundu S, et al. Regulation of monoamine oxidase A (MAO-A) expression, activity, and function in IL-13-stimulated monocytes and A549 lung carcinoma cells. J Biol Chem. 2018;293(36):14040-64. https://doi.org/10.1074/jbc.RA118. 002321

16. Tavakoli-Yaraki M, Karami-Tehrani F, Salimi V, Sirati-Sabet M. Induction of apoptosis by Trichostatin A in human breast cancer cell lines: involvement of 15-Lox-1. Tumour Biol. 2013;34(1):241-9. https://doi.org/10.1007/s13277012-0544-7.

17. O'Donnell VB, Taylor KB, Parthasarathy S, Kühn H, Koesling D, Friebe A, et al. 15-Lipoxygenase catalytically consumes nitric oxide and impairs activation of guanylate cyclase. J Biol Chem. 1999;274(29):20083-91. https://doi.org/1 0.1074/jbc.274.29.20083.

18. Brinckmann R, Schnurr K, Heydeck D, Rosenbach T, Kolde G, Kühn H. Membrane translocation of 15 -lipoxygenase in hematopoietic cells is calcium-dependent and activates the oxygenase activity of the enzyme. Blood. 1998;91(1):64-74. https://doi.org/10.1182/blood.V91.1.64.

19. Tang DG, Bhatia B, Tang S, Schneider-Broussard R. 15-lipoxygenase 2 (15LOX2) is a functional tumor suppressor that regulates human prostate epithelial cell differentiation, senescence, and growth (size). Prostaglandins Other Lipid Mediat. 2007;82(1-4):135-46. https://doi.org/10.1016/j.prostagla ndins.2006.05.022.

20. Roy B, Cathcart MK. Induction of 15-lipoxygenase expression by IL-13 requires tyrosine phosphorylation of Jak2 and Tyk2 in human monocytes. J Biol Chem. 1998;273(48):32023-9. https://doi.org/10.1074/jbc.273.48.32023.

21. Rademacher M, Kuhn H, Borchert A. Systemic deficiency of mouse arachidonate 15-lipoxygenase induces defective erythropoiesis and transgenic expression of the human enzyme rescues this phenotype. FASEB J. 2020;34(11):14318-35. https://doi.org/10.1096/fj.202000408RR.

22. Uderhardt S, Krönke G. 12/15-lipoxygenase during the regulation of inflammation, immunity, and self-tolerance. J Mol Med (Berl). 2012;90(11): 1247-56. https://doi.org/10.1007/s00109-012-0954-4.

23. Philips BJ, Dhir R, Hutzley J, Sen M, Kelavkar UP. Polyunsaturated fatty acid metabolizing 15-Lipoxygenase-1 (15-LO-1) expression in normal and tumorigenic human bladder tissues. Appl Immunohistochem Mol Morphol. 2008;16(2):159-64. https://doi.org/10.1097/PAl.0b013e31 805baa41.
24. Jiang WG, Watkins G, Douglas-Jones A, Mansel RE. Reduction of isoforms of 15-lipoxygenase (15-LOX)-1 and 15-LOX-2 in human breast cancer. Prostaglandins Leukot Essent Fatty Acids. 2006;74(4):235-45. https://doi. org/10.1016/j.plefa.2006.01.009

25. II Lee S, Zuo X, Shureiqi I. 15-Lipoxygenase-1 as a tumor suppressor gene in colon cancer: is the verdict in? Cancer Metastasis Rev. 2011;30(3-4):481-91. https://doi.org/10.1007/s10555-011-9321-0,

26. Gonzalez AL, Roberts RL, Massion PP, Olson SJ, Shyr Y, Shappell SB. 15Lipoxygenase-2 expression in benign and neoplastic lung: an immunohistochemical study and correlation with tumor grade and proliferation. Hum Pathol. 2004;35(7):840-9. https://doi.org/10.1016/j.humpa th.2004.04.001.

27. Hennig R, Kehl T, Noor S, Ding XZ, Rao SM, Bergmann F, et al. 15lipoxygenase-1 production is lost in pancreatic cancer and overexpression of the gene inhibits tumor cell growth. Neoplasia. 2007:9(11):917-26. https://doi.org/10.1593/neo.07565.

28. Jiang WG, Douglas-Jones A, Mansel RE. Levels of expression of lipoxygenases and cyclooxygenase-2 in human breast cancer. Prostaglandins Leukot Essent Fatty Acids. 2003;69(4):275-81. https://doi. org/10.1016/S0952-3278(03)00110-8.

29. Nie D. Cyclooxygenases and lipoxygenases in prostate and breast cancers. Front Biosci. 2007;12(1):1574-85. https://doi.org/10.2741/2170.

30. Subbarayan V, Xu XC, Kim J, Yang P, Hoque A, Sabichi AL, et al. Inverse relationship between 15-lipoxygenase-2 and PPAR-gamma gene expression in normal epithelia compared with tumor epithelia. Neoplasia. 2005;7(3): 280-93. https://doi.org/10.1593/neo.04457.

31. Kort WJ, Bijma AM, van Dam JJ, van der Ham AC, Hekking JM, van der Ingh $\mathrm{HF}$, et al. Eicosanoids in breast cancer patients before and after mastectomy. Prostaglandins Leukot Essent Fatty Acids. 1992;45(4):319-27. https://doi. org/10.1016/0952-3278(92)90090-6.

32. Hong SH, Avis I, Vos MD, Martínez A, Treston AM, Mulshine JL. Relationship of arachidonic acid metabolizing enzyme expression in epithelial cancer cell lines to the growth effect of selective biochemical inhibitors. Cancer Res. 1999:59(9):2223-8.

33. Chocholoušková M, Jirásko R, Vrána D, Gatěk J, Melichar B, Holčapek M. Reversed phase UHPLC/ESI-MS determination of oxylipins in human plasma: a case study of female breast cancer. Anal Bioanal Chem. 2019;411(6):123951. https://doi.org/10.1007/s00216-018-1556-y.

34. Afifi OS, Shaaban OG, Abd El Razik HA, SEA SE-D, Ashour FA, El-Tombary AA, et al. Synthesis and biological evaluation of purine-pyrazole hybrids incorporating thiazole, thiazolidinone or rhodanine moiety as 15-LOX inhibitors endowed with anticancer and antioxidant potential. Bioorg Chem. 2019;87:821-37. https://doi.org/10.1016/j.bioorg.2019.03.076.

35. Tang S, Bhatia B, Maldonado CJ, Yang P, Newman RA, Liu J, et al. Evidence that arachidonate 15-lipoxygenase 2 is a negative cell cycle regulator in normal prostate epithelial cells. J Biol Chem. 2002;277(18):16189-201. https://doi.org/10.1074/jbc.M111936200.

36. Bhatia B, Maldonado CJ, Tang S, Chandra D, Klein RD, Chopra D, et al. Subcellular localization and tumor-suppressive functions of 15-lipoxygenase 2 (15-LOX2) and its splice variants. J Biol Chem. 2003;278(27):25091-100. https://doi.org/10.1074/jbc.M301920200.

37. Tavakoli Yaraki M, Karami Tehrani F. Apoptosis Induced by 13-Shydroxyoctadecadienoic acid in the Breast Cancer Cell Lines, MCF-7 and MDA-MB-231. Iran J Basic Med Sci. 2013;16(4):653-9.

38. Najid A, Beneytout JL, Tixier M. Cytotoxicity of arachidonic acid and of its lipoxygenase metabolite 15-hydroperoxyeicosatetraenoic acid on human breast cancer MCF-7 cells in culture. Cancer Lett. 1989;46(2):137-41. https:// doi.org/10.1016/0304-3835(89)90021-9.

39. Harats D, Ben-Shushan D, Cohen H, Gonen A, Barshack I, Goldberg I, et al. Inhibition of carcinogenesis in transgenic mouse models over-expressing 15-lipoxygenase in the vascular wall under the control of murine preproendothelin-1 promoter. Cancer Lett. 2005;229(1):127-34. https://doi. org/10.1016/j.canlet.2005.02.017.

40. Byler S, Goldgar S, Heerboth S, Leary M, Housman G, Moulton K, et al. Genetic and epigenetic aspects of breast cancer progression and therapy. Anticancer Res. 2014;34(3):1071-7.

41. O'Flaherty JT, Wooten RE, Samuel MP, Thomas MJ, Levine EA, Case LD, et al. Fatty acid metabolites in rapidly proliferating breast cancer. PLoS One. 2013: 8(5):e63076. https://doi.org/10.1371/journal.pone.0063076.

42. Hasegawa T, Yamamoto S, Matsuno Y. Quantitative immunohistochemical evaluation of MIB-1 labeling index in adult soft-tissue sarcomas by 
computer-assisted image analysis. Pathol Int. 2002;52(7):433-7. https://doi. org/10.1046/j.1440-1827.2002.01378.x

43. Natarajan R, Esworthy R, Bai W, Gu JL, Wilczynski S, Nadler J. Increased $12-$ lipoxygenase expression in breast cancer tissues and cells. Regulation by epidermal growth factor. J Clin Endocrinol Metab. 1997;82(6):1790-8. https://doi.org/10.1210/jcem.82.6.3990.

44. Strasser A, Vaux DL. Cell Death in the Origin and Treatment of Cancer. Mol Cell. 2020;78(6):1045-54. https://doi.org/10.1016/j.molcel.2020.05.014.

45. Shen J, Tower J. Programmed cell death and apoptosis in aging and life span regulation. Discov Med. 2009;8(43):223-6.

46. Kazan HH, Urfali-Mamatoglu C, Yalcin GD, Bulut O, Sezer A, Banerjee S, et al. 15-LOX-1 has diverse roles in the resensitization of resistant cancer cell lines to doxorubicin. J Cell Physiol. 2020;235(5):4965-78. https://doi.org/10.1002/ jcp.29375.

47. Zuo X, Shen L, Issa JP, Moy O, Morris JS, Lippman SM, et al. 15Lipoxygenase-1 transcriptional silencing by DNA methyltransferase-1 independently of DNA methylation. FASEB J. 2008;22(6):1981-92. https://doi. org/10.1096/fj.07-098301.

48. Hsi LC, Xi X, Lotan R, Shureiqi I, Lippman SM. The histone deacetylase inhibitor suberoylanilide hydroxamic acid induces apoptosis via induction of 15-lipoxygenase-1 in colorectal cancer cells. Cancer Res. 2004;64(23):877881. https://doi.org/10.1158/0008-5472.CAN-04-1867

49. Hague A, Manning AM, Hanlon KA, Huschtscha LI, Hart D, Paraskeva C. Sodium butyrate induces apoptosis in human colonic tumour cell lines in a p53-independent pathway: implications for the possible role of dietary fibre in the prevention of large-bowel cancer. Int J Cancer. 1993;55(3):498-505. https://doi.org/10.1002/ijc.2910550329.

50. Salimi V, Shabani M, Nourbakhsh M, Tavakoli-Yaraki M. Involvement of 15lipoxygenase-1 in the regulation of breast cancer cell death induced by sodium butyrate. Cytotechnology. 2016;68(6):2519-28. https://doi.org/10.1 007/s10616-016-9972-3.

51. Çolakoğlu M, Tunçer S, Banerjee S. Emerging cellular functions of the lipid metabolizing enzyme 15-Lipoxygenase-1. Cell Prolif. 2018;51(5):e12472. https://doi.org/10.1111/cpr.12472.

52. Kim JH, Hubbard NE, Ziboh V, Erickson KL. Attenuation of breast tumor cell growth by conjugated linoleic acid via inhibition of 5-lipoxygenase activating protein. Biochim Biophys Acta. 1736;2005(3):244-50. https://doi. org/10.1016/j.bbalip.2005.08.015.

53. Connolly JM, Liu XH, Rose DP. Dietary linoleic acid-stimulated human breast cancer cell growth and metastasis in nude mice and their suppression by indomethacin, a cyclooxygenase inhibitor. Nutr Cancer. 1996;25(3):231-40. https://doi.org/10.1080/01635589609514447.

54. Liu XH, Connolly JM, Rose DP. Eicosanoids as mediators of linoleic acidstimulated invasion and type IV collagenase production by a metastatic human breast cancer cell line. Clin Exp Metastasis. 1996;14(2):145-52. https://doi.org/10.1007/BF00121211

55. Rose DP, Connolly JM. Antiangiogenicity of docosahexaenoic acid and its role in the suppression of breast cancer cell growth in nude mice. Int J Oncol. 1999;15(5):1011-5. https://doi.org/10.3892/ijo.15.5.1011

56. Dauchy RT, Dauchy EM, Sauer LA, Blask DE, Davidson LK, Krause JA, et al. Differential inhibition of fatty acid transport in tissue-isolated steroid receptor negative human breast cancer xenografts perfused in situ with isomers of conjugated linoleic acid. Cancer Lett. 2004;209(1):7-15. https:// doi.org/10.1016/j.canlet.2003.12.012.

57. Jelińska M, Białek A, Gielecińska I, Mojska H, Tokarz A. Impact of conjugated linoleic acid administered to rats prior and after carcinogenic agent on arachidonic and linoleic acid metabolites in serum and tumors. Prostaglandins Leukot Essent Fatty Acids. 2017;126:1-8. https://doi.org/10.1 016/j.plefa.2017.08.013.

58. Jelińska M, Białek A, Mojska H, Gielecińska I, Tokarz A. Effect of conjugated linoleic acid mixture supplemented daily after carcinogen application on linoleic and arachidonic acid metabolites in rat serum and induced tumours. Biochim Biophys Acta. 1842;2014(11):2230-6. https://doi.org/10.101 6/j.bbadis.2014.08.013.

59. Białek A, Jelińska M, Tokarz A. Influence of maternal diet enrichment with conjugated linoleic acids on lipoxygenase metabolites of polyunsaturated fatty acids in serum of their offspring with 7,12-dimethylbenz [a] anthracene induced mammary tumors. Prostaglandins Other Lipid Mediat. 2015;116117:10-8. https://doi.org/10.1016/j.prostaglandins.2014.10.001.

60. Nony PA, Kennett SB, Glasgow WC, Olden K, Roberts JD. 15S-Lipoxygenase2 mediates arachidonic acid-stimulated adhesion of human breast carcinoma cells through the activation of TAK1, MKK6, and p38 MAPK. J Biol Chem. 2005;280(36):31413-9. https://doi.org/10.1074/jbc.M500418200.

61. Sauer LA, Dauchy RT, Blask DE, Krause JA, Davidson LK, Dauchy EM. Eicosapentaenoic acid suppresses cell proliferation in MCF-7 human breast cancer xenografts in nude rats via a pertussis toxin-sensitive signal transduction pathway. J Nutr. 2005;135(9):2124-9. https://doi.org/10.1093/ jn/135.9.2124.

62. Dauchy EM, Dauchy RT, Davidson LK, Lynch DT, Krause JA, Blue LM, et al. Human cancer xenograft perfusion in situ in rats: a new perfusion system that minimizes delivery time and maintains normal tissue physiology and responsiveness to growth-inhibitory agents. J Am Assoc Lab Anim Sci. 2006; 45(3):38-44.

63. Comba A, Maestri DM, Berra MA, Garcia CP, Das UN, Eynard AR, et al. Effect of $\omega-3$ and $\omega-9$ fatty acid rich oils on lipoxygenases and cyclooxygenases enzymes and on the growth of a mammary adenocarcinoma model. Lipids Health Dis. 2010;9(1):112. https://doi.org/10.1186/1476-511X-9-112.

64. Blask DE, Dauchy RT, Sauer LA, Krause JA, Brainard GC. Growth and fatty acid metabolism of human breast cancer (MCF-7) xenografts in nude rats: impact of constant light-induced nocturnal melatonin suppression. Breast Cancer Res Treat. 2003;79(3):313-20. https://doi.org/10.1023/A:1024030518065.

65. Blask DE, Dauchy RT, Dauchy EM, Mao L, Hill SM, Greene MW, et al. Light exposure at night disrupts host/cancer circadian regulatory dynamics: impact on the Warburg effect, lipid signaling and tumor growth prevention. PLoS One. 2014;9(8):e102776. https://doi.org/10.1371/journal.pone.0102776.

66. Kozłowski J, Kozłowska A, Kocki J. Breast cancer metastasis - insight into selected molecular mechanisms of the phenomenon. Postepy Hig Med Dosw. 2015;69:447-51. https://doi.org/10.5604/17322693.1148710.

67. Viola K, Kopf S, Huttary N, Vonach C, Kretschy N, Teichmann M, et al. Bay117082 inhibits the disintegration of the lymphendothelial barrier triggered by MCF-7 breast cancer spheroids; the role of ICAM-1 and adhesion. $\mathrm{Br} J$ Cancer. 2013;108(3):564-9. https://doi.org/10.1038/bjc.2012.485.

68. Kerjaschki D, Bago-Horvath Z, Rudas M, SexI V, Schneckenleithner C, Wolbank $S$, et al. Lipoxygenase mediates invasion of intrametastatic lymphatic vessels and propagates lymph node metastasis of human mammary carcinoma xenografts in mouse. J Clin Invest. 2011;121(5):200012. https://doi.org/10.1172/JCl44751.

69. Pasqualini ME, Heyd VL, Manzo P, Eynard AR. Association between Ecadherin expression by human colon, bladder and breast cancer cells and the 13-HODE:15-HETE ratio. A possible role of their metastatic potential. Prostaglandins Leukot Essent Fatty Acids. 2003;68(1):9-16. https://doi.org/1 0.1016/S0952-3278(02)00230-2

70. Boutté AM, McDonald WH, Shyr Y, Yang L, Lin PC. Characterization of the MDSC proteome associated with metastatic murine mammary tumors using label-free mass spectrometry and shotgun proteomics. PLoS One. 2011;6(8): e22446. https://doi.org/10.1371/journal.pone.0022446.

71. Ryman VE, Packiriswamy N, Sordillo LM. Apoptosis of Endothelial Cells by 13-HPODE Contributes to Impairment of Endothelial Barrier Integrity. Mediat Inflamm. 2016;2016:9867138-13. https://doi.org/10.1155/2016/9867138.

72. Blecha JE, Anderson MO, Chow JM, Guevarra CC, Pender C, Penaranda C, et al. Inhibition of IGF-1R and lipoxygenase by nordihydroguaiaretic acid (NDGA) analogs. Bioorg Med Chem Lett. 2007;17(14):4026-9. https://doi. org/10.1016/j.bmcl.2007.04.092.

73. Somvanshi RK, Singh AK, Saxena M, Mishra B, Dey S. Development of novel peptide inhibitor of Lipoxygenase based on biochemical and BIAcore evidences. Biochim Biophys Acta. 1784;2008(11):1812-7. https://doi.org/10.1 016/j.bbapap.2008.07.004.

74. Lee PP, Ip MM. Regulation of proliferation of rat mammary tumor cells by inhibitors of cyclooxygenase and lipoxygenase. Prostaglandins Leukot Essent Fatty Acids. 1992;45(1):21-31. https://doi.org/10.1016/0952-3278(92)90098-4.

75. Reddy N, Everhart A, Eling T, Glasgow W. Characterization of a 15lipoxygenase in human breast carcinoma BT-20 cells: stimulation of 13HODE formation by TGF alpha/EGF. Biochem Biophys Res Commun. 1997; 231(1):111-6. https://doi.org/10.1006/bbrc.1997.6048.

76. Röhrig F, Schulze A. The multifaceted roles of fatty acid synthesis in cancer. Nat Rev Cancer. 2016;16(11):732-49. https://doi.org/10.1038/nrc.2016.89.

77. Nagarajan SR, Butler LM, Hoy AJ. The diversity and breadth of cancer cell fatty acid metabolism. Cancer Metab. 2021;9(1):2. https://doi.org/10.1186/s4 0170-020-00237-2.

78. Koundouros N, Poulogiannis G. Reprogramming of fatty acid metabolism in cancer. Br J Cancer. 2020;122(1):4-22. https://doi.org/10.1038/s41416-0190650-z. 
79. Li D, Li Y. The interaction between ferroptosis and lipid metabolism in cancer. Signal Transduct Target Ther. 2020;5(1):108. https://doi.org/10.1038/ s41392-020-00216-5.

80. Wu X, Liu C, Li Z, Gai C, Ding D, Chen W, et al. Regulation of GSK3B/Nrf2 signaling pathway modulated erastin-induced ferroptosis in breast cancer. Mol Cell Biochem. 2020;473(1-2):217-28. https://doi.org/10.1007/s11010-02003821-8.

81. Salimi V, Shahsavari Z, Safizadeh B, Hosseini A, Khademian N, Tavakoli-Yaraki M. Sodium butyrate promotes apoptosis in breast cancer cells through reactive oxygen species (ROS) formation and mitochondrial impairment. Lipids Health Dis. 2017;16(1):208. https://doi.org/10.1186/s12944-017-0593-4.

82. Han J, Liu Y, Yang S, Wu X, Li H, Wang Q. MEK inhibitors for the treatment of non-small cell lung cancer. J Hematol Oncol. 2021;14(1):1. https://doi. org/10.1186/s13045-020-01025-7.

83. Orafaie A, Matin MM, Sadeghian $\mathrm{H}$. The importance of 15-lipoxygenase inhibitors in cancer treatment. Cancer Metastasis Rev. 2018;37(2-3):397-408. https://doi.org/10.1007/s10555-018-9738-9.

84. Kashyap D, Mittal S, Sak K, Singhal P, Tuli HS. Molecular mechanisms of action of quercetin in cancer: recent advances. Tumor Biol. 2016;37(10): 12927-39. https://doi.org/10.1007/s13277-016-5184-x.

85. Ezzati M, Yousefi B, Velaei K, Safa A. A review on anti-cancer properties of Quercetin in breast cancer. Life Sci. 2020;248:117463. https://doi.org/10.101 6/j.lfs.2020.117463.

86. Fernand VE, Losso JN, Truax RE, Villar EE, Bwambok DK, Fakayode SO, et al. Rhein inhibits angiogenesis and the viability of hormone-dependent and -independent cancer cells under normoxic or hypoxic conditions in vitro. Chem Biol Interact. 2011;192(3):220-32. https://doi.org/10.1016/j.cbi.2011.03. 013.

87. Tahamtan A, Tavakoli-Yaraki M, Shadab A, Rezaei F, Marashi SM, Shokri F, et al. The Role of Cannabinoid Receptor 1 in the Immunopathology of Respiratory Syncytial Virus. Viral Immunol. 2018;31(4):292-8. https://doi.org/1 0.1089/vim.2017.0098.

88. Caffarel MM, Sarrió D, Palacios J, Guzmán M, Sánchez C. Delta9-

tetrahydrocannabinol inhibits cell cycle progression in human breast cancer cells through Cdc2 regulation. Cancer Res. 2006;66(13):6615-21. https://doi. org/10.1158/0008-5472.CAN-05-4566.

89. Sadeghian H, Jabbari A. 15-Lipoxygenase inhibitors: a patent review. Expert Opin Ther Pat. 2016;26(1):65-88. https://doi.org/10.1517/13543776.201 6.1113259.

90. Armstrong MM, Freedman CJ, Jung JE, Zheng Y, Kalyanaraman C, Jacobson MP, et al. A potent and selective inhibitor targeting human and murine 12/ 15-LOX. Bioorg Med Chem. 2016;24(6):1183-90. https://doi.org/10.1016/j. bmc.2016.01.042.

\section{Publisher's Note}

Springer Nature remains neutral with regard to jurisdictional claims in published maps and institutional affiliations.

Ready to submit your research? Choose BMC and benefit from:

- fast, convenient online submission

- thorough peer review by experienced researchers in your field

- rapid publication on acceptance

- support for research data, including large and complex data types

- gold Open Access which fosters wider collaboration and increased citations

- maximum visibility for your research: over $100 \mathrm{M}$ website views per year

At $\mathrm{BMC}$, research is always in progress.

Learn more biomedcentral.com/submissions 